\title{
Status teoretyczny emblematu w polskiej dekoracji
}

\author{
Abstract \\ The Theoretical Status of the Emblem in Polish Decorative Art
}

This paper argues that the theoretical status of the emblem in decorative art has methodological significance in emblem studies and art history, comparable to its status in the so-called book's editorial frame. This claim is justified in the historical and theoretical tradition of defining emblems in the sources. The departure point for the author's considerations comes from the findings of applied emblematics, and its foundation is provided by the theoretical sources describing symbolic genres (scil. emblema, symbolum, hierogliphicum) published in Poland from the 16th to the 18th century, including books of poetics, rhetoric, dictionaries and compendia. The first part of the article presents an overview of research on decorative emblems in Poland, together with factors responsible for the scarcity of such studies, including the lack of symbolic typology of the decorations, and the division into literary and non-literary studies, motivated by the philological roots of emblem studies. It is noted that the emblemata in the so-called book's editorial frame and those in decorations should be studied separately, as the latter are of ornamental nature, and require a distinct order of perception, explication, and the recipient's role. Besides, it is pointed out that the anachronism of the 16th-century formulae of emblema raises problems for the genological classification of Polish decorations, and so does the inter-genre, compendiumtype pattern of symbolism dominant in the 18 th century. The second part of the article discusses the definition of the emblema, focusing on its details relevant for the artistic practice and present-day genre classification, such as technique, composition, the content of the image, which is confronted with Polish historical materials. The analysis carried out in the paper supports the claim that providing a genelogical definition of a work of art sheds light on its artistic rendition and aesthetic value. It also enhances the perspective on emblem studies, the workshop of an emblem artist and the reception of the emblem. Additionally, it enables the verification of synthetic accounts and research practice, offering a profound reflection on the chronology and previous conceptions of the emblem. Finally, it helps to formulate postulates, which can be useful for the methodology of literary emblem studies.
TERMINUS

t. $23(2021)$

z. $3(60)$

s. $227-258$

www.ejournals.eu/

Terminus

emblem theory,

emblem

studies, applied

emblematics,

genology 
Badania nad dekoracjami emblematycznymi w Polsce, choć rozwijające się dopiero $\mathrm{w}$ ostatnich latach, mają długą tradycję, zakorzenioną w dziewiętnastowiecznym zainteresowaniu dla zbiorów emblema. Jednym z najdawniejszych opracowań odnoszących się do tradycji emblematyki jest artykuł poświęcony dekoracji na Jasnej Górze ks. Wacława Kneblewskiego, opublikowany w 1914 rokuㅁ. Żywa musiała być wśród paulinów pamięć o Ambrożym Nieszporkowiczu, autorze Officina emblematum (1680, wyd. 2 zmienione: 1691), ale i samej emblematyki, która w kompleksie jasnogórskim przetrwała w kilku interesujących pod względem formy i treści realizacjach ${ }^{2}$. Historia sztuki dostarcza niemało informacji dotyczących roli i zakresu występowania emblematyki w dziedzictwie artystycznym Rzeczypospolitej. Podobnie jak w przypadku studiów literackich wzrost zainteresowania emblematyką w sztuce był na gruncie polskim pochodną recepcji kompendium Emblematica Arthura Henkela i Albrechta Schöne oraz hasła Williama S. Heckschera i Karla A. Wirtha w Reallexikon zur deutschen Kunstgeschichte ${ }^{3}$. Opracowania powstałe po publikacji monografii Janusza Pelca, artykułu Jana Białostockiego i katalogu wystawy Muzeum Narodowego w Warszawie ${ }^{4}$ dotyczyły dekoracji freskowych ${ }^{5}$ i źródeł graficznych ${ }^{6}$. U podstaw badań nad zabytkami przynależącymi do historycznych granic Pomorza oraz Śląska leżały publikacje niemieckojęzyczne sprzed 1939 roku. Do dziś przedstawienia z ziem Prus i Śląska (część z nich należy do niemieckiej

W. Kneblewski, Freski Dankwarta na Jasnej Górze, „Kronika Diecezji Kujawsko-Kaliskiej” 8 (1914), nr 3, s. 89-94; nr 4, s. 111-120. Pomysł napisania niniejszego artykułu narodził się po interdyscyplinarnym seminarium emblematycznym zorganizowanym przez dr Alicję Bielak (Wydział Artes Liberales UW, Warszawa, 23-24.05.2019 r.). Przywołana w przypisach literatura przedmiotu ma z konieczności charakter wyboru i koncentruje się na pracach najważniejszych z punktu widzenia omawianego zagadnienia. Pani dr Joannie A. Tomickiej oraz Recenzentowi artykułu wdzięczna jestem za lekturę i wszelkie uwagi.

2 Zob. m.in. J. Golonka, Dekoracja malarska kaplicy jasnogórskiej z XVII wieku, w: W kierunku chrześcijańskiej kultury, red. B. Bejze, Warszawa 1978, s. 693-707; D.K. Łuszczek, Jasnogórski refektarz, Warszawa-Częstochowa 1992; M. Karpowicz, Nowe spojrzenie na fresk Biblioteki Jasnogórskiej i jego autora Giuseppe Viscontiego, „Studia Claromontana” 25 (2007), s. 667-682 (tu wcześniejsza literatura przedmiotu).

3 W.S. Heckscher, K.A. Wirth, Emblem, Emblembuch, w: Reallexikon zur deutschen Kunstgeschichte, Bd. 5: Email-Eselsritt, Stuttgart 1959, szp. 85-228; Emblemata. Handbuch zur Sinnbildkunst des XVI. und XVII. Jahrhunderts, Taschenausgabe, hrsg. von A. Henkel, A. Schöne, Stuttgart-Weimar 1996.

4 J. Białostocki, Kompozycja emblematyczna epitafiów śląskich XVI wieku, w: Ze studiów nad sztuką XVI wieku na Ślasku i w krajach sąsiednich, red. B. Steinborn, Wrocław 1968, s. 77-93 (przedruk: idem, Symbole i obrazy w świecie sztuki, Warszawa 1982, s. 200-214); J. Pelc, Obraz-słowo - znak. Studium o emblematach w literaturze staropolskiej, Wrocław 1975; Ars emblematica. Ukryte znaczenia w malarstwie holenderskim XVII w. Katalog wystawy [Muzeum Narodowe w Warszawie], [oprac. J. Michałkowa et al.], Warszawa 1981 .

5 Zob. np. M. Witwińska, Ostrołęcka polichromia Walentego Żebrowskiego, „Biuletyn Historii Sztuki” 23 (1970), nr 3-4, s. 245-259; M. Kurzej, Ikonografia malowideł w zakrystii (tzw. skarbcu) kościoła Dominikanów w Krakowie, w: Sztuka w kręgu krakowskich dominikanów, red. A. Markiewicz, M. Szyma, M. Walczak, Kraków 2013 (Studia i Źródła Dominikańskiego Instytutu Historycznego w Krakowie, 13), s. 787-810.

6 Zob. np. E. Chojecka, Dekoracja malarska ksiag promotionum i diligentiarum Uniwersytetu Jagiellońskiego XVI-XVIII wieku, Kraków 1965 (Zeszyty Naukowe Uniwersytetu Jagiellońskiego XCV, Prace z historii sztuki, z. 3); A. Bentkowska, Symbolika drzewa. Dylematy związane z emblematyczną metoda interpretacji malarstwa, „Rocznik Historii Sztuki” 15 (1985), s. 261-271. 
kultury materialnej) są najlepiej i najkompetentniej opracowanymi w polskiej geografii emblematycznej ${ }^{7}$. Niestety, rozproszone studia i wzmianki dotyczące obiektów i artystów ${ }^{8}$, sporadyczne monografie zabytku ${ }^{9}$, druku ${ }^{10}$ lub odtworzone przez badaczy literatury przypadki artystycznej recepcji konkretnych zbiorów obcych ${ }^{11}$ nie doczekały się podsumowania ani systematycznego omówienia. W Companion to Emblem Studies zasłużyły wprawdzie na wzmiankę, pozostają jednak niewiadomą na emblematycznej mapie Europy ${ }^{12}$.

Podjęta przed laty przez piszącą te słowa próba opracowania katalogu polskiej emblematyki stosowanej ${ }^{13}$ nie powiodła się - potwierdzenie setek wyrywkowych informacji źródłowych i skompletowanie danych na podstawie szeroko zakrojonych kwerend z uwagi na luki w archiwaliach, stanie badań i w dokumentacji konserwatorskiej okazało się pracą niewykonalną dla jednej osoby. Realizację zamierzenia utrudniała prócz artystycznej varietas nieprzystająca do emblematyki literackiej i niemająca zaplecza teoretycznego w źródłach i opracowaniach związanych stricte $\mathrm{z}$ historią sztuki typologia symboliczna rejestrowanych dekoracji. Sprowadzone do

$7 \quad$ Między innymi J. Pokora, Sztuka w służbie reformacji. Ślaskie ambony 1550-1650, Warszawa 1982; J. Harasimowicz, Mors Janua Vitae. Śląkie epitafia i nagrobki wieku reformacji, Wrocław 1992; K. Cieślak, Emblematyka w XVII-wiecznych wnętrzach kościelnych Gdańska, w: Sztuka XVII wieku w Polsce. Materiały Sesji Stowarzyszenia Historyków Sztuki, Kraków, grudzień 1993. Pamięci przyjaciela księdza profesora doktora habilitowanego Janusza Stanisława Pasierba, teologa, poety, historyka sztuki, wielkiego humanisty, red. T. Hrankowska, Warszawa 1994, s. 206-210; K. Cieślak, Emblematic Programmes in Seventeenth-Century Gdansk Churches in the Light of Contemporary Protestantism: An Essay and Documentation, „Emblematica” 9 (1995), no. 1, s. 21-44; eadem, Między Rzymem, Wittenberga a Genewa. Sztuka Gdańska jako miasta podzielonego wyznaniowo, Wrocław 2000, s. 375-379, 387-390; M. Wisłocki, Sztuka protestancka na Pomorzu 1535-1684, Szczecin 2005, s. 29-30, 258-259; K. Kolendo-Korczak, Praecepta politica w toruńskim ratuszu. Niezachowany cykl malowideł z Sali Rady z 1603 roku i jego europejski kontekst, Warszawa 2014.

8 Zob. np. T. Jank, Życie i twórczość malarska brata Adama Swacha (1668-1747), Kraków 2017; M. Kurzej, Depingere fas est. Sebastian Piskorski jako konceptor i prowizor, Kraków 2018, s. 82-112, 197-200.

$9 \quad$ D.K. Łuszczek, Jasnogórski refektarz...; E. Iwanoyko, Apoteoza Gdańska - Program ideowy malowideł stropu Wielkiej Sali Rady w gdańskim ratuszu Głównego Miasta, Gdańsk 1976; M. Marcinowska, Dwór pełen barw. Architektura i dekoracja malarska dworu $z$ Rdzawy w Sąeckim Parku Etnograficznym, Nowy Sącz 1997; K. Kolendo-Korczak, Praecepta politica w toruńskim ratuszu...

10 Zob. np. J. Ostrowski, Flores vitae B. Salomeae, nieznany cykl graficzny Jerzego Eleutera Szymonowicza-Siemiginowskiego, „Biuletyn Historii Sztuki” 35 (1973), nr 1, s. 43-52; A. Kozak, Zwiazki literacko-obrazowe w utworze S. Piskorskiego Flores Vitae B. Salomeae, w: Stowo i obraz. Materiały Sympozjum Komitetu Nauk o Sztuce Polskiej Akademii Nauk, Nieborów, 29 września - 1 października 1977, red. A. Morawińska, Warszawa 1982, s. 113-128.

11 Por. R. Grześkowiak, J. Niedźwiedź, Wstęp, w: M. Mieleszko, Emblematy, wyd. i oprac. R. Grześkowiak, J. Niedźwiedź, red. D. Chemperek, Warszawa 2010, s. 36-47; R. Grześkowiak, Polska recepcja Pia desideria Hermana Hugona. Typy odbioru religijnych zbiorów emblematycznych, w: idem, Dialogi dzieł dawnych. Studia o intertekstualności literatury staropolskiej, Gdańsk 2018, s. 169-218.

12 P.M. Daly, The Emblem in Material Culture, w: Companion to Emblem Studies, ed. by P.M. Daly, New York 2008, s. 419.

13 W artykule używam terminów „emblematyka stosowana” (angewandte Emblematik, applied emblematics), „emblematyka literacka” (literarische Emblematik, literary emblematics), ,emblematyka pozaliteracka” (außerliterarische Emblematik, extra-literary emblematics) w rozumieniach utrwalonych w literaturze przedmiotu. Zob. M. Górska, Ut pictura emblema? Teoria i praktyka, w: Ut pictura poesis/ Ut poesis pictura. O zwiazkach literatury i sztuk wizualnych od XVI do XVIII wieku, red. A. Bielak, opieka naukowa P. Stępień, Warszawa 2013, s. 31-46. 
poziomu tematu ikonograficznego lub interpretacji dzieła sztuki wątki emblematyczne w polskiej historii sztuki ograniczały się najczęściej do charakterystyki pierwowzoru graficznego i inwencji ikonograficznej (np. aktualizacja kostiumologiczna, historyczna lub pejzażowa wzorca przejętego z ryciny). Można w niej również odnaleźć próby porządkowania „elementów emblematycznych” lub wyprowadzoną z ikonologicznych badań szeroką formułę emblematyki ${ }^{14}$. Przedmiotem badań nie była sztuka emblematyczna, ale wyjaśniane na podstawie źródeł symbolicznych wątki alegoryczne i ikonograficzne.

Niniejszy artykuł zrodził się z przekonania, że zagadnienie statusu teoretycznego emblematu w dekoracji/sztuce ma zastosowanie w interdyscyplinarnej praktyce badawczej, wpisując się w ramy historycyzowania i kontekstualizowania współczesnych emblem studies ${ }^{15}$. Dzieło sztuki można definiować genologicznie (tu: w odniesieniu do gatunków literackich), a rozróżnianie wzorów symbolicznych pod względem gatunkowym (nb. współczesne określenie genologiczne dekoracji nie musi być tożsame z terminologią przekazu źródłowego lub wzorca graficznego) otwiera nową perspektywę badawczą, wzbogacając wiedzę o realizacji artystycznej i jej ocenę estetyczną. Z klasyfikacją wiąże się wszak profilowanie badań nad formą i treścią oraz precyzyjne wykorzystanie wniosków wynikających z teorii gatunków i opracowań zbiorów emblematycznych, kompendiów symbolicznych, traktatów impresy etc. Klucz genologiczny umożliwia weryfikację ujęć syntezujących, pogłębienie refleksji na temat chronologii i dawnego rozumienia emblema oraz sformułowanie postulatów istotnych z punktu widzenia metodologii badań nad piśmiennictwem i sztuką. Dzięki analizie terminologicznej obiektu artystycznego możliwe jest poszerzenie wiedzy o warsztacie polskiego emblematysty oraz recepcji emblematyki w dawnej Polsce. Dekoracje są nierzadko jedynym śladem zainteresowania emblematyką w środowiskach, których reprezentanci nie upamiętnili się w Bibliografii Pauliny Buchwald-Pelcowej ani nie zostali rozpoznani jako autorzy emblematów rękopiśmiennych. Podjęcie badań nad genologicznym charakterem emblematyki w sztukach plastycznych możliwe jest dzięki wtórności i kompilacyjności polskiej teorii symbolicznej. Umożliwia je także rozpoznanie mechanizmów recepcji gatunku emblema na ziemiach Rzeczypospolitej.

14 J.A. Chrościcki, Wojna i pokój w przedstawieniach emblematycznych za panowania Wazów, w: Słowo i obraz. Materiały..., s. 129-150; T. Chrzanowski, Emblematyka - sztuka manieryzmu czy baroku?, w: Sztuka baroku. Materiały Sesji naukowej ku czci śp. Profesorów Adama Bochnaka i Józefa Lepiarczyka zorganizowanej przez krakowski oddział Stowarzyszenia Historyków Sztuki i Instytut Historii Sztuki UJ, Kraków, 8-9 czerwca 1990 roku, red. M. Fabiański, K. Kuczman, Kraków 1991, s. 39-46; A. Seidel-Grzesińska, Elementy emblematyczne pomników sepulkralnych w kościele Pokoju w Świdnicy, w: O sztuce sepulkralnej na Śląsu. Materiały z sesji Oddziału Wrocławskiego Stowarzyszenia Historyków Sztuki, 25-26 października 1996 roku, red. B. Czechowicz, A. Dobrzyniecki, Wrocław 1997, s. 87-104.

15 P.M. Daly, Emblem Studies: Achievements and Challenges, w: The International Emblem: From Incunabula to the Internet; Selected Proceedings of the International Conference of the Society for Emblem Studies, 28th July - 1st August, 2008, Winchester College, ed. by S. McKeown, Cambridge 2010, s. 529-531 (Historicising and Contextualising). 
Zagadnienie statusu teoretycznego emblematu $\mathrm{w}$ dekoracji ${ }^{16}$ domaga się namysłu ze względu na wzrost wiedzy o gatunku emblema i sygnalizowany przez badaczy literatury niedostatek studiów poświęconych części obrazowej konstrukcji emblematycznej oraz emblematyce z perspektywy historii sztuki ${ }^{17}$. Mimo publikacji w ostatnim ćwierćwieczu materiałów z konferencji i licznych opracowań monograficznych ${ }^{18}$ poszerzających wiedzę o sztuce emblematycznej i wskazujących jej specyfikę w obrębie emblem studies ${ }^{19}$ trudno oprzeć się wrażeniu, że historia sztuki (nie tylko polska) nie nadążyła za badaniami literaturoznawców.

Dystans i nieprzystawalność badań nad emblematyczną sztuką i literaturą wynika częściowo z filologicznych podstaw i inspiracji emblem studies. Emblematykę literacką traktowano do niedawna nadrzędnie wobec "nieliterackich” przejawów recepcji. Pomimo licznych wzmianek o obrazowości i medialności emblematyki, będących następstwem równorzędności słowa i obrazu w teorii emblema, nie poświęcano ikonowi wiele uwagi ${ }^{20}$. Element obrazowy emblematycznej konstrukcji traktuje się jako ilustrację, a recepcję emblematyki w szeroko pojętej dekoracji ocenia z perspektywy druku. Pojawily się wprawdzie artykuły dowodzące nieadekwatności dawnego podziału na emblematykę literacką i pozaliteracką oraz niezależności dekoracji emblematycznych od wzorów książkowych (podnoszono m.in. inwencyjność i walory poznawcze emblematyki stosowanej, sporadycznie wtórnej wobec zbiorów emblematów $)^{21}$, formułowane przez badaczy postulaty dotyczyły jednak w pierwszej

16 Przedmiotem rozważań niniejszego artykułu jest dekoracja emblematyczna (z perspektywy badań genologicznych domagająca się innego spojrzenia niż emblematyka w ramie wydawniczej - zob. niżej), obserwacje jej dotyczące mogą być jednak użyteczne w analizach szerzej pojętej sztuki emblematycznej.

17 Por. P.M. Daly, Directions in Emblem Research - Past and Present, „Emblematica” 1 (1986), no. 1, s. 168; idem, Emblem Studies: Achievements and Challenges, s. 530; idem, The Emblem in Early Modern Europe: Contributions to the Theory of the Emblem, Farnham-Burlington 2014, s. 151-165.

18 Por. Außerliterarische Wirkungen barocker Emblembücher. Emblematik in Ludwigsburg, Gaarz und Pommersfelden, hrsg. von W. Harms, H. Freytag, München 1975; Emblems and Art History: Nine Essays, ed. by A. Adams assisted by L. Grove, Glasgow 1996; The Emblem and Architecture: Studies in Applied Emblematics from the Sixteenth to the Eighteenth Centuries, ed. by H.J. Böker, P.M. Daly, Turnhout 1999 (tu m.in. A Selective Bibliography of Studies of the Emblem and Architecture, compiled by P.M. Daly and A. MacElwee, s. 247-308); Emblems and Art History. Nine Essays, ed. by A. Adams assisted by L. Grove, Glasgow 1996 (Glasgow Emblem Studies, 1); Die Domänen des Emblems: Außerliterarische Anwendungen der Emblematik, hrsg. von G.F. Strasser, M.R. Wade, Wiesbaden 2004; Architektur als Ort für Embleme. Beiträge zu einer Tagung des Kunsthistorischen Instituts der Christian-Albrechts-Universität $z$ u Kiel am 26.01.2013, hrsg. von I. Höpel, Kiel 2014 (Mundus Symbolicus, 2).

1 Zob. m.in. W. Harms, The Investigation of Emblem Programmes in Buildings: Assumption and Tasks, w: The Emblem and Architecture..., s. 3-16; J. Loach, Architecture and Emblematics: Issues in Interpretation, w: Emblems and Art History..., s. 1-21; eadem, On Words and Walls, w: An Interregnum of the Sign: The Emblematic Age in France. Essays in Honour of Daniel S. Russell, ed. by D. Graham, Glasgow 2001, s. 149-170; S. Mödersheim, The Emblem in the Context of Architecture, w: Emblem Scholarship Directions and Developments: A Tribute to Gabriel Hornstein, ed. by P.M. Daly, Turnhout 2005, s. 158175; P.M. Daly, The Emblem in Material Culture, w: Companion..., s. 411-445; I. Höpel, Einleitung. Architektur als Ort für Embleme - Begriffe, Beispiele, Forschungsaufgaben, w: Architektur als Ort für Embleme..., s. 14; M. Bath, Books and Buildings: Recursive Emblems in the Applied Arts, „Emblematica” 22 (2016), s. 167-192.

20 Szerzej na ten temat: M. Górska, Ut pictura emblema?...

${ }_{21}$ Zjawisko to ilustruje m.in. zbiór z rysunkami J.J. Rollosa, powstały z inspiracji krakowskimi bramami tryumfalnymi ku czci Jana III Sobieskiego, których program powierzono pisarzowi S.J. Bieżanowskiemu: 
kolejności historii emblematyki stosowanej i architektonicznego kontekstu emblematu ${ }^{22}$. Akcentowano raczej odrębność niż paralelność zjawisk. Z literatury przedmiotu nie wynika, do jakiego stopnia syntezy i kategorie filologów, przyjmowane na podstawie badań nad piśmiennictwem i książką, powinny mieć zastosowanie do analiz programów i dzieł emblematycznych. Badania szczegółowe emblematyki stosowanej dotyczyły często impresy ${ }^{23}$, której specyfika (symbolika i autokreacja jednostki) była użyteczniejsza dla dekoracji i artystycznej reprezentacji. Zwracano także uwagę na brak odpowiedniego kontekstu porównawczego ${ }^{24}$. Mimo istnienia licznych rozproszonych studiów brakuje bowiem katalogów i syntez, a podstawową pozycją w bibliografii wciąż pozostaje wzorcowa monografia Cornelii Kemp dotycząca programów emblematycznych w kościołach południowych Niemiec, której metodologiczne propozycje, zwłaszcza związane z eksplikacyjną funkcją scen narracyjnych towarzyszących emblematom (schemat emblema triplex należy do rzadkości w dekoracjach), podejmowano, między innymi analizując retoryczną strukturę dekoracji ${ }^{25}$. W badaniach posługiwano się propozycją egzegetycznego emblematu Heckschera i Wirtha ${ }^{26}$ lub narzędziami sztuki graficznej i ikonologii. Iconologii Cesarego Ripy nie scala się dziś wprawdzie z emblematyką, pozostała jednak punktem odniesienia dla sztuki emblema ze względu na wspólnotę odniesień (por. geneza ikonologii i emblematyki, analogia atrybutu i przedmiotu symbolicznego, inskrypcja przydana personifikacji i lemma), obustronne źródło inwencji i współwystępowanie w programie bądź kompozycji emblematycznej ${ }^{27}$. Prace z historii sztuki emblematu praktycznie nie weszły do polskiego obiegu naukowego. Wciąż obowiązujący wzorzec Henkela i Schöne sprawił, można przypuszczać, że nie doceniono interpretacyjnej i metodologicznej użyteczności emblematyki, ograniczając rozumienie emblema do upowszechnionego przez ten słownik schematu. Jest to szczególnie zastanawiające w przypadku badań nad nieemblematyczną twórczością emblematystów i nad malarstwem sztalugowym, w którym symbolika pojawiała się niewyodrębniona ramami

In laudes Ioannis Sobiescii. Rękopiśmienny zbiór emblematów z rysunkami Johanna Jakoba Rollosa (przeł. B. Milewska-Waźbińska, wstęp i oprac. M. Górska, B. Milewska-Waźbińska, Warszawa 2016); M. Górska, B. Milewska-Waźbińska, Rękopis BK II 263 (obecnie BK 391). Kórnicki zbiór emblematów ku czci Jana III Sobieskiego, w: De nuptiis Philologiae et Libri manuscripti, czyli co nowego mówią rękopisy. Zbiór studiów, red. A.P. Lew, P. Pludra-Żuk, Warszawa 2016, s. 189-212.

22 Zob. prace cytowane w przyp. 18.

23 P.M. Daly, The Emblem in Material Culture...; por. D. Caldwell, The Sixteenth-Century Italian Impresa in Theory and Practice, New York 2004; The Italian Emblem: A Collection of Essays, ed. by D. Mansueto in collaboration with E.L. Calogero, Glasgow 2007; M. Górska, Symbolika heraldyczna a teoria impresy. Przykład Orbis Polonus Szymona Okolskiego, „Rocznik Polskiego Towarzystwa Heraldycznego” seria nowa, 13 (2014), nr 24, s. 35-49.

24 W. Harms, The Investigation of Emblem Programmes..., s. 3.

25 C. Kemp, Angewandte Emblematik in süddeutschen Barockkirchen, München 1981; M. Hundemer, Rhetorische Kunsttheorie und barocke Deckenmalerei. Zur Theorie der Sinnlichen Erkenntnis im Barock, Regensburg 1997.

26 W.S. Heckscher, K.A. Wirth, Emblem, Emblembuch..., szp. 199-200.

27 C.P. Warncke, Symbol, Emblem, Allegorie. Die zweite Sprache der Bilder, Köln 2005, s. 79-88. Por. J. Pelc, Obraz-słowo..., s. 33-34, 99-100; idem, Stowo i obraz. Na pograniczu literatury i sztuk plastycznych, Kraków 2002, s. 23, 47-55, 118-121. 
kartusza. Emblematyka nie stała się również istotnym problemem ani wyzwaniem dla badaczy zjawiska odbioru dzieła sztuki. Podporządkowano ją w badaniach wątkom filiacyjnym, intelektualnym i kulturowym, nie łącząc ściśle z problematyką artystyczną.

Dystansowanie się polskiej historii sztuki wobec emblematyki ma jednak nie tylko materiałowe czy metodologiczne uzasadnienie. Z oczywistych powodów zajmuje się ona obiektami najciekawszymi artystycznie i ikonograficznie lub przynależnymi do oeuvres wybitnych artystów, do czego polska (dotycząca historycznych i współczesnych granic) emblematyka stosowana nie może aspirować poza kilkoma przykładami zainteresowania nią twórców pierwszoplanowych (Izaak van der Blocke, Anton Möller, Tomasz Treter, Jerzy Szymonowicz-Siemiginowski, Michael Willmann, Karol Dankwart, Adam Swach, Walenty Żebrowski, Adrzej Radwański). Więcej uwagi poświęcali jej rzemieślnicy czy freskanci minorum gentium, nierzadko anonimowi twórcy zakonni. Wyobrażenie o dekoracjach reprezentacyjnych (dworu królewskiego, szlachty i mieszczaństwa) kształtują głównie opisy dekoracji okazjonalnych i skromne przekazy ikonograficzne $e^{28}$. Na obronę historii sztuki dodać trzeba, iż problematyka emblematyczna poza ewentualnym nowatorstwem ikonograficznym lub kompozycyjnym, docenianym zwłaszcza w malarstwie ściennym, nie wnosi do dziejów architektury, malarstwa, grafiki czy rzeźby problemów, które umożliwiłyby wyodrębnienie emblematyki jako samodzielnego pola lub narzędzia badawczego. Emblematyka nie przedstawia wszak zagadnień kompozycyjnych, formalnych (warsztatowych) czy estetycznych (np. monochromatyczność ikonu), kwestii recepcji wzorców graficznych ani problematyki ikonografii w sposób, który umożliwiłby wyodrębnienie kategorii emblematycznej lub wzorca emblematycznego, zarówno w dekoracji wielkoformatowej, jak i w przypadku albumu graficznego czy ilustracji ${ }^{29}$. Podobnie kompozycje kartusza i lemmy nie wyróżniają się spośród rozwiązań przyjętych dla innych obramień i inskrypcji.

Rozwoju historii sztuki emblematu nie ułatwiają prowadzone w ostatnich latach badania nad preemblematyką w kontekście typografii i ramy wydawniczej ${ }^{30}$, które

28 Na przykład M. Górska, Dwór i familia. Wizerunek magnaterii w dekoracji okazjonalnej XVIII stulecia, w: Dwory magnackie w XVIII wieku. Rola i znaczenie kulturowe, red. T. Kostkiewiczowa, A. Roćko, Warszawa 2006, s. 111-136; J. Żukowski, Żądza chwały. Władysław IV Waza w ikonografii performatywnej, Warszawa 2018.

29 Wyodrębniany w badaniach problem frontyspisu emblematycznego miał nie tylko artystyczny kontekst: M. Fumaroli, Lécole du silence. Le sentiment des images au XVII siècle, Paris 1994, s. 325-342 (Sur le seuil des livres. Les frontispices gravés des traités d'éloquence, 1594-1641); K.J. Höltgen, Emblematic Title Pages and Frontispieces: The Case of Early Modern Period, w: Companion..., s. 393-409. Por. J. Talbierska, Grafika XVII wieku w Polsce. Funkcje, ośrodki, artyści, dzieła, Warszawa 2011, s. 216, 226-227; M. Cubrzyńska-Leonarczyk, I. Wiencek, Grafika polska w starym druku - terra incognita? Z problemów rejestracji i opracowania, w: Metodologia, metoda i terminologia grafiki i rysunku. Teoria i praktyka, red. J. Talbierska, Warszawa 2014, s. 115-129.

30 Por. B. Czarski, Stemmaty w staropolskich książkach, czyli rzecz o poezji heraldycznej, Warszawa 2012 (Silva Rerum); idem, W poszukiwaniu najstarszego polskiego stemmatu - pytania i propozycje odpowiedzi, „Odrodzenie i Reformacja w Polsce” [w druku]; J. Kiliańczyk-Zięba, Sygnety drukarskie w Rzeczypospolitej XVI wieku. Źródła ikonograficzne i treści ideowe, Kraków 2015; Typographorum Emblemata: The Printer's Mark in the Context of Early Modern Culture, ed. by A. Wolkenhauer, B.F. Scholz, Berlin-Boston 2018. 
podważyły zasadność posługiwania się określeniem „emblematyka” wyłącznie na podstawie kompozycji. Podstawowe dotychczas argumenty na rzecz „emblematyczności” dekoracji - obecność słowno-obrazowej kompozycji lub jej graficzny pierwowzór ze zbioru emblematów - są niewystarczające dla identyfikacji emblematycznego dzieła sztuki. Obramienie, podobnie jak fakt posłużenia się wzorcem graficznym ze zbioru emblematów, nie należy do cech-wyróżników emblema. Historia sztuki polskiej rejestruje przykłady włączania przedmiotów symbolicznych w kompozycje portretów ${ }^{31}$ oraz dekoracje, których emblematyczność, za sprawą luźnego związku kompozycji z przesłaniem zbioru lub odniesień symbolicznych pozostałych elementów, mogła być ograniczona do wzorca graficznego ${ }^{32}$, dekoracyjnej prezentacji symboliki sakralnej ${ }^{33}$ lub wątków mitologicznych ${ }^{34}$.

Zasadne jest również pytanie, do jakiego stopnia emblemata w ramie wydawniczej i w dekoracji są porównywalne jako przedmiot badań. W pierwszym przypadku zaliczenie symbolicznej kompozycji do emblematyki sensu stricto ułatwia konfrontacja wszystkich jej elementów z obowiązującymi w danym miejscu, czasie lub środowisku wzorcami i definicjami emblema. Istotna jest także terminologia używana przez autora lub wykorzystane przez niego źródła. Emblematyczna grafika i sztuka rysunkowa (przeważnie należąca do twórczości nieprofesjonalnej, towarzyszącej projektom i utworom poetyckim) są wszak ściśle związane z ramą wydawniczą (por. frontyspis, stemmat, ilustracja, winieta, sygnet drukarski) i z emblematyką literacką, a ich status - o ile nie mamy do czynienia ze zbiorem graficznym - sprowadzał się najczęściej do emblematycznego ikonu (imago). W przypadku emblemata nuda

$31 \quad$ Najciekawszym znanym mi przykładem jest portret Zofii z Odrowążów Kostkowej (na stole zegar z wizerunkiem Matki Boskiej Bolesnej, z sercem przebitym mieczem, ins. Monstrat vulnere solem, wzór: H. Engelgrave, Lux Evangelica [...], t. 2, Amsterdam: Jacob van Meurs, 1655, s. 63, emb. 5), namalowany w korytarzu pojezuickiego założenia w Jarosławiu jako element dekoracji emblematycznej dedykowanej historii kultu jarosławskiej Piety (A. Swach, 1731). Por. M. Witwińska, Osiemnastowieczna polichromia w jarosławskim kościele „Na Pólku” i jej twórcy, w: Wizerunki maryjne. Archidiecezja przemyska, diecezja rzeszowska. Materiały z VI Seminarium Oddziału Rzeszowskiego Stowarzyszenia Historyków Sztuki „Sacrum et decorum” w Jarosławiu w dniach 16 i 17 listopada 1990 r., z. 1, red. I. Sapetowa, Rzeszów 1992, s. 43-59; M.S. Pielas, Cztery portrety Zofii z Odrowążów Tarnowskiej-Kostkowej, fundatorki kolegium jezuitów w Jarosławiu, „Studia Wilanowskie” 15 (2004), s. 93-107.

32 Na przykład Tarłów, kaplica Z. Oleśnickiego (poł. XVII w.), dekoracja według: O. van Veen, Quintii Horatii Flacci Emblemata, Antwerpen: Hieronymus Verdussen, 1607. Por. A. Koutny-Jones, A Noble Death: The Oleśnicki Funerary Chapel in Tartów, „Journal of the Warburg and Courtauld Institutes” 73 (2009), s. 183-187.

33 Na przykład kilka przedstawień w dekoracji malarskiej (ok. 1614?) kościoła w Nowym Mieście, inspirowanych dziełem Tomasza Tretera Symbolica vitae Christi meditatio (1612). Opis (bez rozpoznania źródła): T. Rudkowski, Polichromia kościoła parafialnego w Nowym Mieście nad Warta (Problemy ikonograficzne), w: Studia nad renesansem $w$ Wielkopolsce, red. T. Rudkowski, Poznań 1970 (Prace Komisji Historii Sztuki, t. 8, z. 3), s. 71-99.

34 Na przykład dekoracja inspirowana Amorum emblemata (1608) Ottona van Veena (Vaeniusa) w Łazience S.H. Lubomirskiego. Zob. M. Karpowicz, Łazienka St. Herakliusza Lubomirskiego. Pierwowzory graficzne dekoracji i próba interpretacji treści, „Biuletyn Historii Sztuki” 31 (1969), nr 4, s. 397-401; idem, Sztuka oświeconego sarmatyzmu. Antykizacja i klasycyzacja w środowisku warszawskim czasów Jana III, wyd. 2 popr. i uzup., Warszawa 1986, s. 54-55; A. Karpiński, J. Krauze-Karpińska, Jesienne porządki w ujazdowskim ogrodzie Stanisława Herakliusza Lubomirskiego. Prywatność publiczna - prywatność prywatna, „Barok” 18 (2011), nr 2 (36), s. 109-129. 
pomijanego, w praktyce pisarskiej niejednokrotnie zastępowanego jednym słowem lub dopełnianego przez wydawcę z wykorzystaniem dostępnych klocków albo płyt graficznych. Hipotetyczne rozróżnienie ikonu zamierzonego i realizacji w druku wydaje się szczególnie istotne w Rzeczypospolitej, gdzie inwencja miała często ograniczenia warsztatowe, a zależność ikonu od obcego wzorca graficznego mogła być następstwem braku umiejętności rzemieślnika. Analiza typologiczna powinna hipotetycznie uwzględniać odrębność projektu i realizacji, także wyobrażeń o emblema autora, rytownika i wydawcy. W drugim przypadku istotna jest także specyfika dekoracji (okazjonalne i stałe, m.in. malowidła freskowe, nagrobki, ołtarze, antepedia, stalle, balustrady chóru muzycznego) oraz obiektów artystycznych nienależących do sztuki książki. Ze względu na charakter projektowy, związek z osobą fundatora, miejscem i czasem powstania status emblematu w ramie architektonicznej, w sztuce użytkowej (np. tapiseria, ornat, dzieło sztuki złotniczej) oraz w samodzielnej z zamysłu inicjatora lub twórcy (tj. koncepcyjnie i formalnie niezależnej od ram architektury i książki czy rękopisu) kompozycji medalierskiej, malarskiej (portret, obraz symboliczny), graficznej lub rysunkowej (np. portret, druk ulotny, teza graficzna, z wyłączeniem kompozycji wtórnie samodzielnych, np. rycin pochodzących $\mathrm{z}$ druku) musiał być odmienny od emblematyki w ramie wydawniczej. Wynikało to $\mathrm{z}$ samego procesu powstania i akcentującej dekoracyjność ikonu funkcji obiektu artystycznego, z którą wiązały się nie tylko ograniczenia, ale i wynikające z miejsca i kontekstu realizacji wymogi i możliwości kompozycyjne i formalne. Inny aniżeli w ramie wydawniczej porządek percepcji i charakter części eksplikacyjnej (kontekst miejsca i funkcji, kompozycje narracyjne) oraz zazwyczaj precyzyjne określenie odbiorcy realizacji nie pozostawało bez wpływu na program emblematyczny, konstrukcję emblematów i ich części składowe ${ }^{35}$. Widoczne jest to zwłaszcza w przypadku programów opracowanych z inspiracji konkretnym zbiorem, gdy wybór, układ i zmiany w zapożyczonych kompozycjach i inskrypcjach dostosowywano dokładnie do określonej społeczności, lokalnych wątków lub dyspozycji pomieszczeń ${ }^{36}$. Analiza programu z pominięciem tej specyfiki, podobnie jak traktowanie lemmy jako elementu kompozycji graficznej, generuje błędy interpretacyjne. Jest to szczególnie dyskusyjne, gdy na podstawie hipotetycznego wzorca graficznego podejmuje się decyzję o odtworzeniu emblematów podczas konserwacji ${ }^{37}$.

Wzrost wiedzy na temat emblema i powiązań sztuki emblematu z innymi gatunkami oraz kulturą symboliczną renesansu i baroku nakazuje ostrożność w posługiwaniu

35 Uwarunkowania architektoniczne emblematyki stosowanej omówione zostały szczegółowo w pracach J. Loach i S. Mödersheim (zob. przyp. 18).

36 Zob. M. Górska, Dekoracja emblematyczna Sali Pospólstwa w Ratuszu Tarnowskim. Przykład polskiej recepcji Cardiomorphoseos (1645) Francesca Pony, „Rocznik Tarnowski” 13 (2008), s. 27-43; eadem, Emblematyczna dekoracja fasad kolegium jezuitów w Toruniu (1701). Antyprotestancki program wedtug Imago primi saeculi Societatis Iesu (1640), „Zapiski Historyczne” 74 (2009), z. 1, s. 7-32.

37 Ch. Moisan-Jablonski, Źródła inspiracji i symbolika regencyjnych „bram tryumfalnych” zdobionych emblematami z kościoła pw. Św. Tomasza Apostoła w Nowym Mieście Lubawskim, w: Europa, Rzeczpospolita, Prusy Królewskie. Nowożytność, red. D. Dettlaff, Puck 2018, s. 101-133. Por. M. Górska, Dekoracje emblematyczne w Lubawie i w Nowym Mieście Lubawskim [w druku]. 
się pojęciem „wzorca emblematycznego”, zwłaszcza gdy uświadomimy sobie stylistyczną rozmaitość szesnastowiecznej emblematyki, hieroglifiki, włoskiej impresy czy francuskiej dewizy. Badania prowadzone nad emblematyką wykazały również lokalną specyfikę recepcji, w przypadku Rzeczypospolitej łączoną ze stemmatem. W sztuce relacja emblemata-stemmata dostrzegana była w kompozycjach graficznych i w twórczości okazjonalnej ${ }^{38}$. W perspektywie nowszych badań nad emblematyką i jej teorią heraldyka nie jest jednak wyłączana z emblematyki sensu stricto, wiadomo również, w jakiej relacji pozostawała ona $\mathrm{z}$ hieroglifikiem i symbolem heroicznym (symbolum heroicum) ${ }^{39}$.

Pomimo chaosu terminologicznego, obserwowanego w pismach teoretycznych i nazewnictwie dzieł emblematycznych z XVI-XVIII wieku, odrębność gatunków symbolicznych w ówczesnej refleksji jest faktem niepodważalnym ${ }^{40}$. Choć gatunki te traktowano paralelnie, a formuły definicji się zmieniały, wskazując potrzebę wprowadzenia cezur chronologicznych, nie ma podstaw do przesadnej ostrożności terminologicznej lub posługiwania się wywiedzionymi z teorii gatunku literackiego kategoriami „pograniczności” lub „hybrydyzacji” ${ }^{4}$. Współczesne definicje i opisy emblematu literackiego, sprowadzane do szesnastowiecznych formuł (m.in. Paolo Giovia, Johana Pontanusa), są anachroniczne wobec zdecydowanej większości utworów i realizacji artystycznych. Historyk sztuki bada przeważnie dekoracje powstałe w drugiej połowie XVII i w XVIII wieku wedle kompendiów i zbiorów należących do zapomnianych pozycji z obszernej spuścizny emblematycznej, dla których więcej analogii odnaleźć można w słabo przebadanej emblematyce osiemnastowiecznej, odmiennej formalnie i terminologicznie ${ }^{42}$.

Badacz sztuki emblematycznej musi mieć świadomość z jednej strony niezależności wzorca ikonograficznego lub kompozycyjnego od genologii, z drugiej zaś wpływu, jaki na projektodawców i artystów miał ponadgatunkowy wzorzec

38 Zob. P. Buchwald-Pelcowa, Na pograniczu emblematów i stemmatów, w: Słowo i obraz. Materiały..., s. 73-95; J. Bednarska, Z dziejów polskiej ilustracji panegirycznej pierwszej połowy XVII wieku, cz. 2: Problematyka stylistyczno-formalna polskiej panegirycznej ilustracji książkowej, Katowice 2005; eadem, Z dziejów polskiej ilustracji panegirycznej drugiej połowy XVII wieku, cz. 3: Studium z zakresu ikonografii i problematyki stylistyczno-formalnej, Katowice 2016; J. Liškevičienè, XVI-XVIII amžiaus knygų grafika. Herbai senuosiuose lietuvos spaudiniuose, Vilnius 1998; E. Patiejūniene, Brevitas ornata. Mãžosios literatūros formos XVI-XVII amžiaus lietuvos didžiosios kunigaikštystès spaudiniuose, Vilnius 1998; B. Czarski, Stemmaty...

39 Por. P.F. Campa, The Space Between Heraldry and the Emblem: The Case of Spain, w: Emblem Scholarship Firections and Fevelopments: A Tribute to Gabriel Hornstein, ed. by P.M. Daly, Turnhout 2005, s. 51-82; A.R. Young, The Emblem and Flags, w: Companion..., s. 457-476; M. Górska, Symbolika heraldyczna...

40 Zob. np. T. Michałowska, Staropolska teoria genologiczna, Wrocław 1974; M. Górska, Hieroglifik $w$ teorii Rzeczpospolitej (XVII-XVIII w.). Zarys problematyki, „Terminus” 14 (2012), z. 25, s. 15-46.

${ }_{41}$ Por. P. Buchwald-Pelcowa, Na pograniczu emblematów i stemmatów..., s. 73-95; B. Czarski, Lemmata $w$ staropolskich konstrukcjach stemmatycznych jako przejaw hybrydyzacji gatunkowej, „Terminus” 14 (2012), z. 25, s. 157-178.

42 M. Górska, Emblematyka w Rzeczypospolitej epoki oświecenia - metamorfozy tradycji symbolicznej, „XVIII amžiaus studijos” 6 (2020), s. 140-159; eadem, Emblematyka czasów stanisławowskich - problematyka terminologiczna dekoracji okazjonalnych, w: ,Skłócony naród, król niepewny, szlachta dzika?”. Polska stanisławowska w świetle najnowszych badań, red. P. Ugniewski, Warszawa 2020, s. 35-60. 
kompendiów (m.in. Filippo Picinelli, Jacobus Boschius). Zakorzeniony w nadrzędnej wobec emblema czy hierogliphicum teoretycznej formule „symboliki”, upowszechnił się za sprawą recepcji popularnych podręczników (m.in. Nicolasa Caussina, Maximiliana Sandaeusa, Claude’a-François Ménestriera, Jacoba Masena). Jak szeroka mogła być to formuła, pokazuje powstała pod wpływem Cannocchiale aristotelico (1654) Emanuele’a Tesaura teoria Ménestriera ${ }^{43}$. Klasyfikacji gatunkowej nie ułatwiają również popularne w osiemnastowiecznej Rzeczypospolitej kompendia Johanna Michaela von der Kettena (Apelles symbolicus, 1691, według Ménestriera Philosophia imaginum, 1695) i Benedykta Chmielowskiego (Nowe Ateny..., 1745-1746; wyd. 2: 1754-1756). W przypadku dzieła von der Kettena, reprezentanta zakonu brygitanów, wzorzec „symboliki” wynikał z przeprowadzonej przezeń analizy dostępnych zbiorów (także medalierskich) i traktatów oraz z dostrzeżenia wielości formuł i definicji ${ }^{44}$. Późniejsza praca Chmielowskiego była kompilacją dzieł Picinellego i Masena, a zaproponowane w niej definicje gatunków - następstwem pojmowania przez tych autorów symbolum ${ }^{45}$. Apelles symbolicus i Nowe Ateny, dzieła autorów trudniących się również opracowaniem programów dekoracji, odzwierciedlają jednak problematykę terminologiczną i praktykę ich czasów. Dowodzą, że pojęcia „symbol” i „symbolika" nie tylko nie są deprecjonujące z punktu widzenia badań nad emblema, ale ułatwiają i wzbogacają analizę, bez konieczności tworzenia podtypów zacierających cechy wspólne gatunków symbolicznych ${ }^{46}$. Tezy o wszechobecności „emblematyki” w kulturze staropolskiej oraz jej braku w epoce oświecenia w świetle nowszych polskich i obcych badań wymagają weryfikacji.

Za sprawą niespójności zarówno w dawnej, jak i współczesnej terminologii i teorii emblematu (emblema) emblematykę traktuje się dziś jako formułę ponadgatunkową, obejmującą rozmaicie określane słowno-obrazowe konstrukcje przynależne do kultury renesansu i baroku. Posługiwanie się terminem „emblematyka” oznacza jednak rezygnację z możliwości głębszej analizy dzieła i jego przesłania, z określenia genologicznie rozróżnianej relacji słowa i obrazu w kompozycji oraz z wykorzystania dzieł sztuki jako źródła uzupełniającego do poznania piśmiennictwa emblematycznego i gatunków symbolicznych. Zagadnienie statusu teoretycznego emblematu

43 J. Loach, Menestrier's Emblem Theory, „Emblematica” 2 (1987), no. 2, s. 317-336.

44 J.M. von der Ketten, Apelles symbolicus exhibens seriem amplissimam symbolorum [...], AmsterdamGdańsk: J. Janssonius Van Waesberge - Erven, 1699, t. 2, k. nlb. 3r.-8v. (Catalogus auctorum qui in re symbolica scripserunt). Zob. M. Górska, Apelles symbolicus (1699) Johanna Michaela von der Kettenaźródto wiedzy o niezachowanych emblematach i inskrypcjach warszawskich, w: Kultura artystyczna Warszawy XVII-XXI w. Studia, red. Z. Michalczyk, A. Pieńkos, M. Wardzyński, Warszawa 2010, s. 97-109.

45 B. Chmielowski, Nowe Ateny. Umbry objaśnione, oprac. J. Kroczak, J. Sokolski, wstęp J. Sokolski, Wroclaw 2015.

46 Analogicznie ponadgatunkowe historyczne znaczenie pojęcia „Sinnbild” w badaniach niemieckich wykorzystuje się w badaniach nad gatunkami literackimi w sztuce. C.P. Warncke, Symbol...; por. J. Sokolski, Barokowa ksiega natury. O europejskiej symbolografi wieku siedemnastego, Wrocław 1992; idem, Symbol, w: Słownik literatury staropolskiej. Średniowiecze - renesans - barok, red. T. Michałowska, przy udziale B. Otwinowskiej, E. Sarnowskiej-Temeriusz, wyd. 2, Warszawa 1998 (Vademecum Polonisty), s. 917-923; F. Vuilleumier Laurens, La raison des figures symboliques à la Renaissance et à l'âge classique. Etudes sur les fondements philosophiques, théologiques et rhétoriques de limage, Genève 2000. 
w dekoracji uzasadnia metodologicznie kontekst historyczny i teoretyczny emblema. W świetle polskiej teorii gatunków symbolicznych (scil. definicje w obrębie szkolnych poetyk i retoryk oraz kompendiów symbolicznych XVII-XVIII w.) nie ma rozdziału między emblematem w sztuce i piśmiennictwie (wynikało to z uretorycznienia ówczesnej kultury $)^{47}$. W egzemplifikacji równorzędnie traktowano przykłady artystyczne i literackie. Hipotetycznie można zatem przyjąć, że dzieła sztuki dostarczają wskazówek dotyczących specyfiki gatunkowej, także wówczas, gdy brakuje źródeł pisanych, które by potwierdziły emblematyczność zabytku, odsłoniły jego przesłanie czy wyświetliły autorstwo programu emblematycznego i rolę zleceniodawcy w procesie jego powstania. Każda dekoracja miała wszak podstawę w projekcie obejmującym koncepcję ideową (poprzedzającym projekt stricte artystyczny), a zachowane dokumenty tego typu ${ }^{48}$ przekonują o zasadności stawiania pytania o ich podstawę teoretyczną, także w przypadku braku archiwaliów. Polskie źródła do badań nad teorią gatunków symbolicznych nie zawierają jednoznacznych formuł i normatywnych rozstrzygnięć, umożliwiają jednak (zwłaszcza te, które posługują się stwierdzeniami kategorycznymi) ${ }^{49}$ udzielenie odpowiedzi na pytania, gdzie szukać i jak rozpoznać emblemat w dekoracji oraz odróżnić emblemat (emblema) od innych kompozycji, zwłaszcza od symbolu (symbolum) i hieroglifiku (hierogliphicum) oraz od przedstawienia opatrzonego sentencją (sententia) lub inskrypcją (inscriptio). Hierarchizacja problemów i uwagi praktyczne teoretyków, odzwierciedlające stan wiedzy i oczekiwania polskiego odbiorcy, nie pozostawały bez wpływu na dekoracje emblematyczne.

Polska teoria gatunków symbolicznych, będąca kompilacją definicji pochodzenia stricte emblematycznego (np. Claude Mignault) i jezuickiej teorii symboliki (m.in. Caussin, Silvestro Pietrasanta, Masen), przefiltrowanych przez tradycję hieroglifiki i włoskiej impresy, umożliwia odtworzenie w sposób hipotetyczny statusu teoretycznego emblematyki stosowanej. Pomimo terminologicznej wieloznaczności i wielomianowości w założeniu autorów ujęcia te miały charakter całościowy, regulujący lub arbitralny ${ }^{50}$. Ze względu na sprawozdawczy charakter są pośrednio źródłem wiedzy o niezachowanych dekoracjach lub zaginionej emblematyce, zwłaszcza jej popularności w sztuce użytkowej, której reprezentacji zachowało się do naszych czasów niewiele.

47 Prezentację emblema $\mathrm{z}$ konieczności ograniczę w tym miejsu do spraw najistotniejszych z punktu widzenia niniejszego artykułu. Szerzej: M. Górska, The Definition of the Emblem: Models and Norms of the Genre: The Polish Perspective, w: Non-Classical Genres - Theory and Practice (Series: Early Modern Genre Theories and the Practice of Writing) [w druku].

48 Zob. np. E. Iwanoyko, Emblematyczne Sobiesciana Gotfryda Peschwitza, „Artium Quaestiones” 2 (1983), s. 11-33; A. Betlej, Jan Stanisław Jabłonowski a sztuka w świetle jego pamiętników, „Barok” 13 (2006), z. 2 (26), s. 163-186 (na podstawie: BN rkps BOZ 814); K. Kolendo-Korczak, Praecepta politica..., s. 315-362 (Aneksy).

49 Na przykład Biblioteka Kórnicka PAN [dalej: Kór. PAN] rkps 600, k. 11: „[emblemma] difert a simbolo rigoroso".

50 Por. A. Brożek, Przyczynki do teorii definicji, „Filozofia Nauki/The Philosophy of Science” 26 (2018), nr 2 (102), s. 125, 127-128, 131, 135, 140. 
Standardem były definicje, które ze względu na grecki źródłosłów pojęcia przywoływały rozmaitość technik wykonania emblema - mozaikowa, rzeźbiona, malowana, ryta, haftowana etc. Niekiedy pisano wprost o wykorzystaniu kamieni szlachetnych (perły, gemmae), kruszców (np. złoto, srebro), marmuru i alabastru ${ }^{51}$. Odpowiadało to tradycyjnej definicji i rozumieniu słowa emblema w kontekście wprawienia (insertio, iniectio), które zadecydowało o łączeniu z pojęciem ornamentu architektonicznego naczyń lub tkanin ${ }^{52}$.

Informacje dotyczące genezy i związanych z nią uwag materiałowych i technicznych ukierunkowane były na charakterystykę gatunku (wprawienie oznaczało uzyskanie sensu $)^{53}$, uzupełniając definicję emblema jako opus elegans ${ }^{54}$, do której zwłaszcza od drugiej połowy XVII wieku - dokomponowywano reprezentacyjną ramę architektoniczną i artystyczną, znaną z apartamentów dworskich, pałaców i budowli kościelnych ${ }^{55}$. W źródłach teoretycznych odnaleźć można niemało informacji o lokalizacji dekoracji emblematycznej. Pisząc o emblematyce sakralnej, wymieniano nagrobki (sepulchrum, tumulus) ${ }^{56}$, epitafia ${ }^{57}$ i ołtarze, o dekoracjach okazjonalnych - łuki tryumfalne ${ }^{58}$, o założeniach rezydencjonalnych - sień/przedsionek (atrium), gabinet i bibliotekę oraz ogród, który był przestrzenią funkcjonowania emblematycznych form dekoracji do czasów stanisławowskich ${ }^{59}$.

Emblematami można było ozdobić portyk (porticulus), ściany (parietes), posadzki (pavimentes, solum), sklepienie (camera), powałę (tectus) lub strop kasetonowy (lacunar, laquear), także kolumny (columnae) i bazy (bases) ${ }^{60} . Z$ wyposażenia wymieniano obrazy (tabulae, także mozaikowe) i posągi (statuae), stół (mensa), szpaler (tapiseria), parawan; z przedmiotów rzemiosła naczynia metalowe i szklane (vases, m.in. kielich - scyphus, puchar - poculum), tkaniny (tela), ubiory (vestes, vestimenta), broń

51 Na przykład Biblioteka PAN i PAU w Krakowie [dalej: Kr. PAN] rkps 1332, k. 51v.; Lwowska Narodowa Naukowa Biblioteka Ukrainy im. W. Stefanyka, fond 4, opys 1 [dalej: Baw.], rkps 457, k. 30v.

52 Na przykład Baw. rkps 477, k. 14v.; Kr. PAN 1332, k. 51v.; Biblioteka Litewskiej Akademii Nauk w Wilnie [dalej: AWil.] rkps F41-612, s. 8.

53 Por. np. Biblioteka Jagiellońska w Krakowie [dalej: BJ] rkps sygn. 7200 I, s. 79: „Emblema idem significat quod insertum seu insitum"; A. Szulc, Orbis quod vult in obiectis centum scientiarium [...], Danzig, David Friedrich Rhete, 1682, s. 151: „Emblema significat insertionem, quod insertum sibi sensum habeat"; Baw., rkps 477, k. 14v.: „Emblema est insertio certarum figurarum in artefactis operibus”.

54 Na przykład Baw. rkps 476, k. 32v. Por. Biblioteka Uniwersytetu Wileńskiego [dalej: UWil.], rkps F3-2087, k. 71r.: „opus aliquod sculpturae v[el] picturae elegantis".

55 Por. UWil. rkps F3-2217, k. 91r.: „Emblematib[us] plen[us] e[st] mund[us] praecipue aulae Principu[m]”; Biblioteka Narodowa w Warszawie [dalej: BN] rkps I 6881, k. 29v.: „Exemplum symbolorum et emblematum plurima enim videri poterint tum in templorum, tum in palatiorum parietibus [...]".

$56 \quad$ Na przykład UWil. rkps F3-2087, k. 71r.-71v.; Kr. PAN rkps 1332, k. 51v.

57 Na przykład Kór. rkps 624, k. 104v. Por. M. Gołąbek, Epitafium Anny Pisarskiej w krużgankach dominikańskich w Krakowie, „Barok” 11 (2004), nr 1 (21), s. 41-54.

$58 \quad$ Na przykład Kór. rkps 624, k. 83r.

59 B. Chmielowski, Nowe Ateny..., s. 81. Por. Jardin sentimental du château de Warkland, dans le comté de Borch, en Russié Blanche, [Warszawa: s.n.] 1795.

60 Por. Baw. rkps 457, k. 30v.; Baw. rkps 711, k. 9v.; Kr. PAN rkps 1332, k. 51v.; UWil. rkps F3-1521, s. 39; BJ rkps 4273, k. 277r.; Biblioteka Książąt Czartoryskich w Krakowie [dalej: BCz.] rkps 2050, s. 18; A. Temberski, Via Appia ad eloquentiae lauream [...] seu facilis modus proficiendi in rhetoricis [...], Poznań: Drukarnia Kolegium Jezuitów, 1712, s. 289-290. 
(arma, np. tarczę - clipeus, miecz - gladius) ${ }^{61}$ oraz przedmioty związane z symboliką prawną: pieczęć (sigillum), pierścień/sygnet (anulus), chorągiew (vexillum), znaki zaszczytne/insygnia (insygnes) ${ }^{62}$. W XVIII wieku, ewidentnie pod wpływem zmiany form dekoracji, pozbawiono emblema odniesienia do mozaiki (świadczy to zarazem o utracie filiacji z renesansowym toposem retorycznym ${ }^{63}$, łącząc emblemat przede wszystkim ze słowem pictura, z „obrazami” a „malowaniem”, gdy jeszcze pod koniec poprzedniego stulecia między rzeźbą a malarstwem stawiano znak równości ${ }^{64}$. Pomijając tu teoretyczne znaczenie obrazu, podkreślić trzeba, że termin pictura stał się w definicjach wyróżnikiem emblema na tle innych definicji (w przypadku symbolu i hieroglifiku posługiwano się częściej pojęciem imago) ${ }^{65}$, a kontekst przedstawienia artystycznego prowadził nierzadko do określenia elementu słownego kompozycji emblematycznej jako dodanego do obrazu ${ }^{66}$.

Wytyczne dotyczące sposobu wprawienia kompozycji i techniki wykonania świadczyły o pojmowaniu emblematyki w kategoriach reprezentacyjności i dekoracyjności. Wskazania te znajdują potwierdzenie w materiale zabytkowym i źródłach pisanych. Polski dorobek emblematyczny obejmował szeroko pojętą oprawę ceremonialną i sztukę reprezentacyjną (realizacje dla króla, osób świeckich i duchownych, przedstawicieli władz miasta), w XVIII wieku znajdując zastosowanie głównie w malarstwie ${ }^{67}$. Można przypuszczać, że kres popularnych w XVII wieku emblematycznych dekoracji stropów czy portali (znanych z opisów bram tryumfalnych) przyniosły zmiany zachodzące w dekoracji reprezentacyjnej drugiej połowy

${ }_{61}$ Na przykład AWil. rkps F41-612, s. 8; Baw. rkps 457, k. 30v.; Baw. rkps 711, k. 9v.; UWil. rkps F3-2087, k. 71r.-71v.; AWil. rkps F9-19, k. 36r.; Kr. PAN rkps 1332, k. 51v.; AWil. rkps F41-612, s. 8; Biblioteka Zakładu Narodowego im. Ossolińskich we Wrocławiu [dalej: Oss.] rkps 1712/I, k. 8r.; A. Temberski, Via Appia..., s. 289-290.

62 Na przykład AWil. rkps F9-19, k. 36r.; Kr. PAN rkps 1332, k. 51v.; UWil. rkps F3-2087, k. 71r.-71v.; AWil. rkps F41-612, s. 8; Baw. rkps 463, k. 25v.; Kór. rkps 624, k. 104v.

63 Por. E. MacPhail, The Mosaic of Speech: A Classical Topos in Renaissance Aesthetics, „Journal of the Warburg and Courtauld Institutes" 66 (2003), s. 249-263.

64 Na przykład BCz. rkps 2455 I, s. 299: „Emblemata [...] nihil aliud sunt, quam pictura[e] [...]”; BCz. rkps 2373 I, s. 107: „emblema est pictura”; B. Chmielowski, Nowe Ateny..., s. 79. Por. AWil. rkps F9-19, k. 36r.: ,[Emblemata] sunt picturae seu sculpturae [...]”.

65 Różnice te widoczne są także w definicjach tego samego skryptu, np. Kór. rkps 619, k. nlb. 13r. Por. R. Dekoninck, Ad Imaginem. Status, fonctions et usages de l'image dans la littérature spirituelle jésuite du XVII siècle, Genève 2005; idem, Maximilianes Sandaeus (1578-1656) théoricien de l'image mystique et symbolique, w: Emblematic Images and Religious Texts. Studies in Honor of G. Richard Dimler, S.J., ed. by P.F. Campa, P.M. Daly, St. Joseph 2010, s. 171-181.

${ }_{66}$ Por. określenia adiectio, addicitur, np. Kr. PAN rkps 556, k. 118r.; AWil. rkps F9-330, k. 13r.

67 Zob. m.in. M. Stahr, Medale Wazów w Polsce. 1587-1668, Wrocław 1990; R. Kaczmarek, J. Witkowski, Dekoracja malarska kaplicy Ksiażęcej w Lubiażu. Najwcześniejsze prace freskowe Willmanna, w: Willmann $i$ inni. Malarstwo, rysunek i grafika na Ślasku i w krajach ościennych $w$ XVII i XVIII wieku, red. A. Kozieł, B. Lejman, Wrocław 2002, s. 82-91; A. Mosingiewicz, D. Kaczor, Emblematyka w służbie władzy. Adama Jacoba Martiniego corpus emblematicum, czyli projekt choragwi gdańskich straży obywatelskich z okazji intrady Ludwiki Marii Gonzagi do Gdańska w 1646 r., w: Sztuka w kręgu władzy. Materiały LVII Ogólnopolskiej Sesji Naukowej Stowarzyszenia Historyków Sztuki, poświęconej pamięci Profesora Szczęsnego Dettloffa (1878-1961) w 130. rocznicę urodzin, Toruń, 13-15 listopada 2008, red. E. Pilecka, K. Kluczwajd, Warszawa 2009, s. 161-178; J. Żukowski, Żądza chwały... 
XVII wieku oraz jej francuskie wzorce ${ }^{68}$. Wyobrażenie o nich dają zachowane relikty (np. dekoracja kamienicy Gerarda Kleinpoldta w Warszawie, dekoracja dworu z Rdzawy) oraz odpowiadające dekoracjom świeckim wystroje reprezentacyjnych ciągów komunikacyjnych i pomieszczeń klasztornych (np. refektarz, kapitularz, biblioteka ${ }^{69}$. Skromne przykłady emblematycznych mebli i przedmiotów rzemiosła, także ich odwzorowań w rękopisach ${ }^{70}$, dają z kolei wyobrażenie o tym, w jaki sposób polska emblematyka występowała poza ramą architektoniczną.

Uwydatniające odmienność zastosowanych technik, rozbudowane (nierzadko znacznych rozmiarów) kompozycje obramień i kartuszy (również malowanych) uznać można za znak rozpoznawczy emblematyki. W przypadku malarstwa ściennego wykorzystywano i podkreślano podziały architektoniczne (np. sklepienie krzyżowe, luneta, wysklepek), dodając nierzadko naśladujące obramienia ornamentacyjne malowane złocenia. Owa techniczna strona emblematyki ma wytłumaczenie w przywoływanych wyżej szczegółach definicji i w ówczesnej leksykografii. Słowem emblema (ta) nie zawsze bowiem określano emblematy w dzisiejszym rozumieniu tego pojęcia. Do lat czterdziestych XVII wieku słowniki polskie i z Polską związane termin emblema rozumiały jako „sadzenie”, mozaikową dekorację złożoną z tesser, wykorzystywaną do ozdoby mebli lub połączenie różnych materiałów w dekoracji stropu i ścian ${ }^{71}$, także jako wyrób stolarski lub złotniczy ${ }^{72}$. Jezuita Grzegorz

$68 \quad$ Na przykład dekoracje powstałe według La doctrine des moeurs (Paris, L. Sevestre, P. Daret, 1646; kolejne wyd. pt. Le Théâtre moral de la vie humaine, Bruxelles, F. Foppens, 1672; kolejne wyd. 1678, 1702; zbiór z inspiracji dziełem Ottona van Veena, Quinti Horatii Flacci Emblemata, 1607) Marina Le Roy, sieur de Gomberville, oraz C.F. Ménestrier, Philosophia imaginum [...], Amsterdam-Gdańsk, J. Janssonius Van Waesberge - Erven, 1695, s. 567-568 (Miscellanea et additamenta varia, X. Adoro quien me a tormenta/ Adoro excruciantem/ J'adore qui me tourmente). Zob. M. Karpowicz, Sala Horacego $w$ Starym Otwocku. Z rozważań nad antykizacja treści, w: Muzeum i twórca. Studia z historii sztuki i kultury ku czci prof. dr Stanisława Lorentza, [kom. red. K. Michałowski et al.], Warszawa 1969, s. 327-347; idem, Sztuka oświeconego sarmatyzmu..., s. 120-138; D. Matyaszczyk, Pałac w Konarzewie, „Ochrona Zabytków” 52 (1999), nr 3 (206), s. 261-262, il. 13. Szerzej o wzorcach francuskich: M. Górska, Recepcja francuskich książek emblematycznych i zbiorów symboli w Rzeczypospolitej XVII i XVIII wieku, w: Francusko-polskie relacje artystyczne w epoce nowożytnej, red. A. Pieńkos, A. Rosales Rodriguez, Warszawa 2010, s. 55-65.

69 Na przykład D.K. Łuszczek, Jasnogórski refektarz...; R. Nowak, Zapomniane malowidła freskowe Michała Willmanna w pałacu opackim w Lubiążu, „Roczniki Sztuki Śląskiej” 14 (1986), s. 97-116; M. Marcinowska, Dwór pełen barw...; M. Górska, Dekoracja emblematyczna warszawskiej kamienicy Gerarda Kleinpoldta, „Barok” 22 (2015), nr 1 (43), s. 107-127.

70 Zob. Pax et Bonum. Skarby klarysek krakowskich. Katalog wystawy. Arsenat, Muzeum Czartoryskich, wrzesień-październik 1999, red. A. Włodarek, Kraków 1999 (dekoracja klasztornej szafy na podstawie Flores vitae B. Salomeae (1691) S. Piskorskiego); P. Birecki, Skrzynka cechu piwowarów na tle XVIII-wiecznej intarsji toruńskiej, „Rocznik Muzeum w Toruniu” 10 (2001), s. 177-211; R. Grześkowiak, Polska recepcja Pia desideria..., s. 177, 179 (szafa zakrystii kościoła Nawrócenia św. Pawła Apostoła w Sandomierzu, ok. 1710, wzór: H. Hugon, Pia desideria, 1624). Por. rysunki skrzynek i waz emblematycznych: BCz. rkps 1867 IV: Orsa rhetorica, seu utriusq[ue] eloque[n] tiae flores inter nominales Orsae rosas bienio editi: Ad meliorem eruditionis frugem Regalib[us] Iagellonia manipuli auspicijs provecti, et duos in manipulos colligati. Anno 1696, s. 179, 181, 183, 185, 187, 189, 289, 291, 293, 295, 297, 299, 301.

71 Zob. np. J. Mączyński, Lexicon Latino-Polonorum, Królewiec: Jan Daubmann, 1564, k. 102r.

72 Zob. np. A. Calepinus, Dictionarium undecim linguarum, Basel: Heinrich Petri, 1558, s. 474; P. Dasypodius, Dasypodius Catholicus, hoc est Dictionarium Latino-Germanico-Polonicum, Germanico-Latinum et Polono-Latino-Germanicum [...], Gdańsk: Andrzej Hünefeld, 1642, k. nlb. r. (hasło Emblema). 
Knapiusz początkowo ograniczał rozumienie emblema do sztuki złotniczej i „sadzenia"”3, dopiero w wydaniu z 1644 roku jego popularnego słownika uzupełniono definicję wzmianką o emblemacie literackim, zredagowaną na podstawie formuły Pontanusa ${ }^{74}$. W polskiej kulturze i języku obok znaczenia stricte genologicznego funkcjonowało równolegle do XVIII wieku rozumienie emblema jako niekoniecznie symbolicznej dekoracji wprawionej w większą ramę kompozycyjną ${ }^{75}$. Do piśmiennictwa emblematycznego zalicza się dzieła, w których pojęciem emblematu określono obraz, ornament, rycinę lub kartusz z przedstawieniem symbolicznym ${ }^{76}$.

Rozumienie terminu pozbawione odniesień genologicznych pojawiało się również w obrębie definicji emblema przy okazji prezentacji antycznego źródła i kontekstu historycznego pojęcia, potwierdzając na polskim gruncie, iż preemblematyczne znaczenia terminu okazały się kluczowe dla rozumienia gatunku w XVI i XVII wieku $^{77}$. Z inspiracji pismami jezuitów Caussina (De eloquentia sacra et humana, 1619), Pietrasanty (De symbolis heroicis..., 1634) i Masena (Elogia sacra..., 1664), odnoszących się do tradycji antycznej, średniowiecznej i nowożytnej emblema, starożytną praktykę zdobienia emblematami tarcz i chorągwi łączono z genezą heraldyki ${ }^{78}$. Opisywane w skryptach antyczne emblemata pięczętne, medalierskie lub ryte na tarczach uzasadniały zainteresowanie staropolskiej emblematyki dla emblemata politica, symbola heroica oraz impres czy dewiz władców i postaci upamiętnionych w historii. W konsekwencji około czwartej ćwierci XVII wieku dawne znaczenie pojęcia łączono niekiedy z ornamentem, a współczesne między innymi z heraldyką̧ ${ }^{79}$, utożsamiano terminy emblemata i stemmata oraz uznawano za emblema przedstawienie herbu opatrzone sentencją ${ }^{80}$. Dzięki źródłom teoretycznym wiadomo dziś, dlaczego około połowy XVII wieku znaczenie historycznego emblema łączono niekiedy z wprawionymi ozdobami, a metaforyczne z wierszami objaśniającymi obrazy,

73 G. Knapiusz, Thesauri Polono Latino Graeci [...] tomus secundus Latinopolonicus [...], Kraków: Franciszek Cezary, 1626, s. 250 (hasła Emblema oraz Emblema vermiculatum).

74 J. Pelc, Stowo i obraz..., s. 38-39.

75 Por. opis dekoracji w Dobromilu Jana Szczęsnego Herburta z początku XVII wieku: Emblemata Izby Dobromilskiej, Kór. PAN rkps 318, s. 61-63; J.A. Chrościcki, La simbologia del potere nella decorazione di Dobromil, „Odrodzenie i Reformacja w Polsce” 39 (1995), s. 123-132.

76 Por. P. Buchwald-Pelcowa, Emblematy w drukach polskich i Polski dotyczacych XVI-XVIII wieku. Bibliografia, Wrocław 1981, s. 78 (poz. 15), 81 (nr 23), 114 (nr 140).

77 Por. D.S. Russell, The Term “Emblème” in Sixteenth-Century France, „Neophilologus” 59 (1975), s. 337351; A. Bagley, English Dictionary Definition of “Emblem” and “Device” from Elyot to Johnson, „Emblematica” vol. 4 (1989), no. 1, s. 177-199; D.L. Drysdall, Occurences of the Word „Emblema” in Printed Works before Alciato, „Emblematica” 14 (2005), s. 299-325; P.F. Campa, Emblematic Terminology in the Spanish Tradition, w: Aspects of Renaissance and Baroque Symbol Theory 1500-1700, ed. by P.M. Daly, J. Manning, New York 1999, s. 13-26; M. Bath, Inserts and Suppressions: Seventeenth-Century Poetic Usage of the Term "Emblem", w: Emblem Studies in Honour of Peter M. Daly, ed. by M. Bath, P.F. Campa, D.S. Russell, Baden-Baden 2002, s. 1-14.

78 Na przykład Baw. rkps 457, k. 31v.: „ex hieroglyphicorum et emblematum usu, accepisse originem stemmata”.

79 Na przykład ibidem, k. 30v.-31r.

80 Na przykład Baw. rkps 219, k. 3r.; G. Knapiusz, Thesauri polonolatinograeci [...] Tomus secundus Latino Germano Polonicus [...] Editio nova correctior, Poznań: Drukarnia Kolegium Jezuitów, 1698, s. 300. 
rzeźby i dekoracje teatralne ${ }^{81}$. $Z$ definicji wyprowadzić można również uwagi praktyczne dotyczące opracowania obiektów artystycznych, zwłaszcza powstałych do XVII wieku. Emblema odnotowane w źródle nie musiało być realizacją gatunku emblematu w rozumieniu dawnym ani współczesnym; z emblematyki jako przedmiotu badań nie powinno się wyłączać wyodrębnionych z ramy kompozycyjnej przedstawień odpowiadających tematyce emblema (zob. niżej) pozbawionych inskrypcji ani opatrzonego inskrypcją symbolu insygnialnego lub heraldycznego, określanych dziś najczęściej (wykluczająco wobec emblematyki) terminem stemmata ${ }^{82}$.

Współczesną klasyfikację genologiczną obiektu powinna poprzedzać szczegółowa analiza wszystkich elementów kompozycji. Normatywizm polskiej teorii emblema dotyczył w pierwszej kolejności kontekstu i tematu, sprawę liczby komponentów emblema i ich kompozycji traktując rozmaicie. Zdarzały się definicje wymieniające trzy elementy (części składowe określano różnie), częściej dwa, sporadycznie jeden inskrypcję lub obraz ${ }^{83}$. Pisano o maksymalnie trzech elementach lub realizowano wzorzec emblema multiplex ${ }^{84}$. Liczba elementów nie może być zatem decydująca dla określenia specyfiki gatunkowej, podobnie ich układ, mimo iż w skryptach pojawiają się uwagi praktyczne formułowane na podstawie wzorca graficznego lub wynikające z interpretacji elementów słownych emblema. Proponowano bowiem umieszczać ikon między lemmą a epigramem ${ }^{85}$ lub rozróżniać emblemat od symbolu na podstawie części słownej usytuowanej pod lub nad ikonem ${ }^{86}$. Wskazówek tych nie można traktować jako reguł, zwłaszcza w przypadku emblematyki stosowanej, gdy ze względów kompozycyjnych inskrypcje włączano w pole ikonu lub umiejscowienie i układ taśmy inskrypcyjnej podporządkowywano podziałom architektonicznym lub projektowi kartusza.

Dla badacza użyteczniejsza jest koncepcja emblematycznego sensu uzyskanego za sprawą zmiany kontekstu (por. insertio) ${ }^{87}$ oraz analiza dodatku inskrypcyjnego, mimo iż w przypadku ograniczenia powierzchni lub kompozycji dłuższe inskrypcje nie miały zastosowania w artystycznej symbolice. Przykładów podwójnej inskrypcji

${ }_{81}$ Zob. UWil. rkps F3-2126, k. 3v.-4r.

82 Por. M.A. Trotz, Nouveau dictionnaire françois, allemand et polonois [...], t. I, Leipzig: Johann Friedrich Gleditsch, 1747, szp. 2124: „1. Emblema, malowanie godłowe; obraz z napisem przyłożonym; 2. symbolum, godło, hasło, ktore sobie kto na pamiątkę obrał; 3. godło, napis herbowny; 4 . napis tkany albo wyszywany na wstędze kawalerskiej orderu jakiego; 5. napis in emblemate".

83 Zob. np. A. Szulc, Orbis..., s. 148.

${ }^{84}$ Na przykład UWil. rkps F-2075, k. 275v.: „tria maxime ad emblema requiruntur”; UWil. rkps F3-1364, s. 120: „emblema [...] ad picturas carmina rem illustrantia aut plures inscriptiones, quae clarius rem explicant, adiunctas habet". Por. D. Graham, Emblema Multiplex: Towards a Typology of Emblematic Forms, Structures and Functions, w: Emblem Scholarship Directions..., s. 131-158.

85 Na przykład J. Kwiatkiewicz, Svada civilis huius aevi genis et nostratis politiae ingenio [...] accomodata [...], Kalisz: Drukarnia Jezuitów, 1672, s. 255; Baw. rkps 1483, k. 23r.

${ }^{86}$ Na przykład Kr. PAN rkps 1747, k. 40v.: „in emblemate ponit infra subscriptio, symbolum subscriptionem supra habet.”; UWil. rkps F3-2267, k. 65v.: ,in emblemate, dat[ur] subscriptio infra pictura[m] hic [scil. in simbolo] supra picturam inscriptio”; B. Chmielowski, Nowe Ateny..., s. 79: „lemma albo napis nad nim [scil. ciałem-figurą malowaną]".

87 Na przykład BJ rkps 3546, k. 9v.: „[Emblema] Est insertio certarum figuraru[m] in artefactis operibus ut vasis, clypeis, est saepe sine inscriptione, designat aliquid". 
zachowało się niewiele w polskiej dekoracji, a ich uzasadnieniem była raczej precyzja scholastyczna lub propagandowa niż wierność definicji emblema ${ }^{88}$. Badania szczegółowe pokazały, że funkcję komentarza, łączonego z emblematyczną subskrypcją, przejmował kontekst artystyczny i historyczny miejsca. Pomimo określonej formuły lemmy, funkcjonującej również jako samodzielny gatunek ${ }^{89}$, pojawiają się w pismach teoretycznych wzmianki świadczące o tym, że starano się wyróżniać jej wersję emblematyczną. Mylono wprawdzie czasem emblematyczne dodatki słowa w kompozycji emblema (w definicjach stosowano pojęcia: 1) lemma, inscriptio, epigraphe, dictum, inscriptio poetica, subscriptio, sententia; 2) epigramma, elogium, epigraphe, epigraphe metrica, carmen, poema, versus, metrum, subscriptio), z rozproszonych uwag wynika jednak, że krótka (brevis), jasna (clara), czasem także dowcipna (acuta) inskrypcja emblematu mogła być dłuższa niż lemma symbolu ${ }^{90}$. Dodatek inskrypcyjny emblematu mógł być cytatem (np. z pism oratorskich lub poezji), passusem początkowym lub końcowym mowy lub wiersza ${ }^{91}$. Istotne, że w przypadku lemmy symbolu (była najważniejszym elementem tego gatunku) metryczność i formę wierszowaną wyłącznie dopuszczano, akcentując głównie brevitas, określaną czasem precyzyjnie jako jedno-dwa, maksymalnie trzy-cztery słowa ${ }^{92}$. Choć funkcja lemmy symbolicznej i emblematycznej była analogiczna, inskrypcja emblematu nie była elementem niezbędnym ani nie miała charakteru decydującego dla sensu kompozycji, autorzy definicji skupiali się na ikonie, trzecim elemencie emblema lub akcentowali dla przekazu rolę słowa i obrazu ${ }^{93}$. Istotniejsza aniżeli charakterystyka elementów kompozycji była dla nich koncepcja emblema jako wyobrażenia prawdy i obyczajów (mores), prezentacji cnót, występków, właściwości i godności, także cnót teologicznych i kardynalnych oraz funkcja moralnego pouczenia, upomnienia lub pochwały ${ }^{94}$.

Znamienne, że sentencja ${ }^{95}$ lub inskrypcja samodzielna (inscriptio), tak popularne w budowlach Rzeczypospolitej, nie były przeważnie włączane do konstrukcji symbolu ani emblematu jako zrozumiałe bez konieczności zestawienia ich z „obrazem” ${ }^{\circ}$.

88 Na przykład w dekoracji kaplicy Cudownego Obrazu na Jasnej Górze (K. Dankwart, 1694-1695) i w o1tarzu bocznym w kościele parafialnym pw. św. Jana Chrzciciela i św. Jana Ewangelisty w Świerczynkach (koniec XVII w.). Por. Katalog zabytków sztuki w Polsce, t. 11, red. T. Chrzanowski, M. Kornecki, z. 16: Powiat toruński, oprac. T. Chrzanowski, M. Kornecki, Warszawa 1972, s. 65-66.

89 Por. M. Kucała, Opuszczenia składników wypowiedzi-sentencji emblematycznych z XVII wieku, w: Studia z historii języka polskiego i stylistyki historycznej ofiarowane profesor Halinie Wiśniewskiej na 50-lecie jej pracy naukowo-dydaktycznej, red. C. Kosyl, Lublin 2001, s. 111-117; M. Górska, O staropolskiej lemmie w teorii i praktyce, „Teksty Drugie” (2019), nr 2, s. 241-258.

90 Na przykład Oss. rkps 5333/I, s. 164: „Emblema differt p [er] hoc solum a simbolo stricte sumpto quod p[er] picturam longiorem inscriptionem admittat"; B. Chmielowski, Nowe Ateny ..., s. 80.

${ }_{91}$ Na przykład Kr. PAN rkps 1747, k. 80v.-81r.; BN rkps akc. 2013, k. 29v.

$92 \quad$ Na przykład UWil. rkps F3-2103, k. 24v.; Oss. rkps 5176/I, s. 52; BCz. rkps 2455 I, s. 537.

93 Na przykład PAN Kr. rkps 557, k. 27r.; BN rkps akc. 2013, k. 29r.: „per picturam v[el] lemma ac epigramma explicans".

94 Na przykład UWil. rkps F3-1067, s. 144; Baw. rkps 414, s. 57; BJ rkps 2723 I, k. 42v.; BG PAN rkps Ms. 2808, k. 9r.; BJ rkps 3278 I, k. 92r.; AWil. rkps F255-1469, k. 33v.

95 Sentencję sporadycznie akceptowano w teorii emblema, np. UWil. rkps F3-2126, k. 4r.

96 Na przykład Baw. rkps 478, k. 256v.: „Inscriptiones longiores ab emblemate et symbolo differunt, quia propriis verbis res exponitur et imaginibus, picturis ac allegoriis carere possunt"; ibidem, k. 258r.: 
Sprawa dla ówczesnych odbiorców była oczywista, o czym zaświadcza wzmianka Chmielowskiego o dekoracji ogrodu w Cucułowcach Jerzego Stanisława Dzieduszyckiego czy przekaz Karola Żery odniesiony do inskrypcyjnej mody XVIII wieku'

Prezentacja ikonu zajmowała mniej miejsca w teorii aniżeli uzasadniające naturę emblematu kwestie formalne, jednak precyzja zaleceń oraz ich związek z tematyką i funkcją gatunku sprawiają, że uwagi dotyczące emblematycznej pictura wydają się decydujące dla genologicznych badań emblematyki artystycznej. Obraz emblematu kontrastowano z enigmatycznością hieroglificznego znaku i z prostotą ikonu symbolu, sporadycznie stąd ograniczano część pictura do jednego elementu. Wyróżnikiem emblema były kompozycja złożona oraz formuła uniwersalna, dopuszczające przedstawienia rzeczy prawdziwych lub zmyślonych oraz postaci rzeczywistych lub fikcyjnych, ludzi i bogów ${ }^{98}$. Istotne, że owej rozbudowanej kompozycji obce było rebusowe złożenie, niemające uzasadniania w porządku natury lub narracji. Znakiem czasu jest, że na przełomie XVII i XVIII wieku kojarzono ją z reprezentacyjnością, w przypadku wątpliwości co do liczby postaci w ikonie odsyłając do dekoracji i malarstwa dworskiego ${ }^{99}$. Mające genezę $\mathrm{w}$ teoretycznym toposie emblema rozważania o pełnej figurze oraz kompozycji figuralnej sprowadzano do zalecenia postaci pełnej (wyobrażenia części ciała były znakiem rozpoznawczym hieroglifiku i symbolu) oraz wyobrażeń dwóch lub większej liczby osób ${ }^{100}$.

Zalecenia te wynikały $\mathrm{z}$ tematyki. W XVII wieku emblematycznemu obrazowi przypisywano cztery zakresy tematyczne: historię, bajkę, historię naturalną i problematykę moralną ${ }^{101}$. Akcentowano zwłaszcza tematykę obyczajową i pouczenie moralne, w materiale egzemplifikacyjnym definicji przywołując najchętniej przykłady dotyczące historii (zwł. antycznej) i mitologii ${ }^{102}$. Zalecano również umieszczać w ikonie przedstawienia zwierząt, ptaków i kwiatów ${ }^{103}$.

„Emblema differt ab inscriptione, quae picturam necessario n[on] requirunt”. Por. P. Labbé (L’Abbé), Elogia sacra, theologica et philosophica regia, eminentia, illustria, historica, poetica, miscellanea, accessere Stephani Petiot panegyrici duo [...], Leipzig: Johann Friedrich Gleditsch, 1686, s. 604-605, 614.

97 Zob. B. Chmielowski, Nowe Ateny [...], Lwów: Drukarnia Kolegium Jezuitów, 1756, t. 2, s. 301-302: „Były różne sztuki i pułapki na mostach dla uciechy, inskrypcje po gmachach wyborne dla erudycji”; K. Żera, Fraszki i opowiadania, wyd. Z. Gloger, Warszawa 1893, s. 111: „[szlachta, plebani] kładą rozmaite napisy i malowidła na ścianach wewnątrz izb między szpalerami, nad drzwiami, kominkami, na belkach, okiennicach i parawanach [...]". Por. R. Grześkowiak, Firlejów jako Nowe Ateny. Nieznane emblematy Benedykta Chmielowskiego, w: Świt i zmierzch baroku, red. M. Hanusiewicz, J. Dąbkowska, A. Karpiński, Lublin 2002, s. 490.

98 Na przykład Baw. rkps 478, k. 258v.; AWil. rkps F255-1469, k. 33v.; UWil. rkps F3-2267, k. 64v.; Kór. PAN rkps 600, k. 10v.-11r.; UWil. rkps F3-1812, k. 32r.

99 Na przykład w poetyce z XVII/XVIII w. - BN rkps I 6881, k. 28v.: „Si plures res pingunt viventes dignior officis, aut aliquo simili principalem locum”; A. Temberski, Via Appia..., s. 289: „,Valere, ut videre est in aulaeis scite textis, vel in picturis aularum".

100 Na przykład Kr. PAN rkps 1747, k. 40v., 44r.; BJ rkps 7200 I, s. 79. Por. J.J.G. Arranz, La imagen desconcertada: teoría y práctica en la representación de la figura humana en las Imprese, w: Estudios sobre emblemática española. Trabajos del grupo de investigación Literatura emblemática hispánica (Universidade da Coruña), Edición al cuidado de S. López Poza, Ferrol 2000, s. 65-80.

101 Na przykład Oss. rkps 1170/I, k. 37v.-38r.

102 Na przykład Baw. rkps 454, k. 13v.; Kór. PAN rkps 600, k. 11r.

103 Kr. PAN rkps 1332, k. 51v. 
Ze względu na charakter polskiego materiału zabytkowego (dochowały się głównie dekoracje w kościołach i klasztorach) w pismach teoretycznych sprzed czwartej ćwierci XVII wieku zwraca uwagę luźny związek definiowanej emblema z tematyką sakralną. Niewykluczone, że ze względu na genezę emblema i jej świeckie konteksty, wiążące się z reprezentacją i heraldyką, emblematy sensu stricto łączono w pierwszej kolejności z tematyką profanum. Być może wynikało to także z adresata skryptów teoretycznych oraz $\mathrm{z}$ akcentowania kontekstu sacrum $\mathrm{w}$ definicjach hieroglifiku. Nawet w kręgu jezuickim ograniczano emblemat do trzech typów (physicum, historicum, morale/ethicum), pomijając teologiczny (theologicum), w teorii Sandaeusa wiążący się z tematyką Starego i Nowego Testamentu ${ }^{104}$. Odzwierciedlająca się w sztuce sakralnej i piśmiennictwie popularność Pia desideria emblematis elegiis et affectibus SS. Patrum illustrata (1624) Hermana Hugona i zbiorów kordialnych nie znajduje uzasadnienia w staropolskiej teorii emblema ${ }^{105}$. Dopiero od czwartej ćwierci XVII wieku akcentuje się w niej wątki sakralne. W kompendium Antoniego Szulca z 1682 roku pojawia się podział emblemata na ecclesiastica („quae vel sanctorum laudem innuunt vel ad pietatem Christianam inducunt”), scholastica („quibus universitates professoresque, ad studia incitentur, et propter studia magnificantur”) oraz epithalamica („quibus amatoria addenda, si castae sint Cynthiae”) ${ }^{106}$. Typ teologiczny (theologicum - „rem fidei [explicans] ${ }^{107 ”)}$ zaczyna być wymieniany również pośród rozbudowanych prezentacji emblematu, obok emblema określanych jako: naturale („rem naturalem [explicans]”), artificiale („re[m] artefactam [explicans]”), historicum („historiam [explicans]”), apophtegmaticum („dictum alicujus illustre [explicans]”), poeticum („fabulam aliquam [exprimens]”) i hierogliphicum („figura alicuius animalis more Aegiptiorum [explicans]") ${ }^{108}$. Polska teoria dopuszczała bowiem zamianę hieroglifiku w emblemat.

Przywołane klasyfikacje zacierają ważny dla pojmowania emblematyki do połowy XVII wieku kontekst filologiczny (związek emblematu z epigramem) i polityczny, upamiętniony w dekoracjach powstających na zlecenie mieszczan i w kręgu dworu królewskiego ${ }^{109}$. Nie przez przypadek w wykładzie z lat czterdziestych XVII wieku definiowano wyłącznie emblemata politica, rozumiejąc je jako

104 Oss. rkps 1712/I, k. 8r. Por. M. van der Sandt, Theologia symbolica. In qua origo symbolorum, eorumq[ue] artificium, ex Sacra Scriptura potissimum eruitur et eiusdem symbola omnis generis explicantur [...], Mainz: Johann Theobald Schönwetter, 1626, s. 172.

105 R. Grześkowiak, Polska recepcja Pia desideria..., s. 169-218.

106 A. Szulc, Orbis..., s. 148.

107 Wszystkie uzupełnienia w nawiasach kwadratowych w cytowanych fragmentach pochodzą ode mnie - M.K.G.

108 Cyt. na podstawie BN rkps akc. 2013, k. 29r. Por. T. Michałowska, Staropolska teoria..., s. 169.

109 Por. W. Kryczyński, Pałac podhorecki w roku 1717. Opis podług inwentarza z 1717 roku, Złoczów 1914, s. 66, 71; Z. Bania, Pałac w Podhorcach, „Rocznik Historii Sztuki” 13 (1981), s. 116, 130-131 (dot. niezachowanej dekoracji pałacu S. Koniecpolskiego, inspirowanej zbiorem J. Typotiusa, Symbola divina et humana pontificum, imperatorum, regum, Praha: [Jiří Černý (Nigrin)], 1601-1603); U. Gulbińska-Konopa, Ł. Konopa, Odnalezione wzory graficzne późnorenesansowych polichromii w tzw. Piwnicy pod Fortuna w kamienicy Lubomelskich w Lublinie, „Tabularium Historiae” 3 (2018), s. 77-112. 
obrazowe monita z lemmą służące obronie Rzeczypospolitej ${ }^{110}$. Emblematyczne „tkaniny” Andrzeja Maksymiliana Fredry (Peristromata regum seu memoriae principis monitorum, symbolis expressum, w: Scriptorum seu togae et belli notationum fragmenta, 1660) odzwierciedlają tę tradycję, adaptowaną w ówczesnych zaleceniach pedagogicznych ${ }^{111}$.

Staropolska teoria w zaskakujący sposób uwydatnia malarskość i narracyjność emblematyki na tle pozostałych gatunków symbolicznych. Uzmysławia, jak ważny i inspirujący dla polskiej emblematyki XVII wieku okazał się wzorzec dworski. Po połowie stulecia jego wersja francuska stała się niewątpliwie konkurencyjna wobec emblematyki epoki humanizmu oraz symboliki heroicznej, dla której wzorcowe były przede wszystkim dzieła Jacobusa Typotiusa oraz Pietrasanty, związane z włoską impresą. Popularność „historycznego” rozumienia emblematu otwiera z drugiej strony możliwości zaliczenia do emblema przedstawień niewiązanych przeważnie z gatunkiem z powodu braku inskrypcji lub nieposługujących się charakterystycznym kodem symbolicznym (przedstawienie wyodrębnione kartuszem). W przypadku polskich dekoracji charakter emblematyczny mogły mieć narracyjne przedstawienia zaczerpnięte z mitologii lub historii antycznej, których emblematyczność wyrażała się w zestawieniu ich ze scenami bliższymi polskiej rzeczywistości (np. scenami z historii Polski) lub innego rodzaju kompozycje-nośniki znaczeń wprawiane w większe dekoracje ${ }^{112}$.

Dawna teoria emblematu odsłania uproszczenia współczesnych analiz, zachęcając do przyglądania się szczegółom oraz wykraczania poza treści związane $\mathrm{z}$ pierwowzorami graficznymi. Odtworzenie wpisanych $\mathrm{w}$ program emblematyczny aluzji symbolicznych i słownych prezentuje w innym świetle problemy ikonograficzne (wybór motywów i atrybutów), tłumacząc również estetyczne wybory projektodawcy lub twórcy, które bez znajomości zasad emblema i kontekstu symbolicznego mogą być uznane za zapóźnione stylistycznie w relacji do ówczesnej sztuki projektowania. Staropolska teoria wskazuje połowę XVII wieku jako ważną cezurę polskich dekoracji. Wydaje się, że do tego czasu emblema poza ramą wydawniczą było pojmowane jako element tradycji antycznej i formuła historyczna $^{113}$ - być może był to wzorzec istotniejszy niż publikowane poza granicami Rzeczypospolitej definicje znane ze wstępów zbiorów lub traktatów emblematyki. Teoretyczne zapiski uczą ponadto odrębnego traktowania emblematyki osiemnastowiecznej, powstającej przeważnie pod wpływem kompendiów (wzorcowych także dla ikonu).

110 UWil. rkps F3-2132, k. 106r.

111 J. Pastorius, Palaestra nobilium seu consilium de generosorum adolescentum educatione in gratiam quorundam Illustrium Polonorum conscriptum, Elbląg: nakładem autora, Achacy Korel, 1654, s. 82-83.

112 Por. W. Bystrzonowski, Informacyja matematyczna rozumnie ciekawego Polaka świat cały, niebo i ziemię, i co na nich jest, $w$ trudnych kwestiach i praktyce, jemuż ułatwiająca, Lublin: Drukarnia Jezuitów, 1743 , k. nlb. (\$ XXXI. O ozdobieniu części kolumnacyi).

113 Por. J. Kowalczyk, Medaliony na pałacu Suchorabskich-Radziwiłłów w Lublinie i ich pierwowzory graficzne, w: Studia nad sztuka renesansu i baroku, t. 4, red. J. Lileyko, Lublin 2000, s. 7-57. 
Wyróżnikiem emblema w formule symboliki była tematyka ikonu i formuła inskrypcji. Trzeba podkreślić, że w świetle wykorzystanych źródeł teoretycznych symbolum było wobec emblematu przeważnie gatunkiem nadrzędnym - bardziej kunsztownym i wymagającym od autora, przez odniesienia do symbolum heroicum silniej związanym z heraldyką i sztuką konceptu. Emblema kojarzone było z instruktażem doktrynalnym i moralnym oraz ze szkołą, co w połączeniu z narracyjnością i eksplikacyjną funkcją inskrypcji musiało mieć wpływ na lokalizację dekoracji i ich tematykę. Świadczą o tym między innymi programy dekoracji w założeniu pijarskim w Rzeszowie oraz w refektarzach klasztoru jasnogórskiego i kolegium jezuitów w Grudziądzu ${ }^{114}$. Kojarzone z emblematyką odniesienia uniwersalne i doktrynalna prawowierność kwalifikowały emblematyczną sztukę do scholastycznych wykładów i religijnych polemik. Wśród realizacji z pierwszej połowy XVIII wieku zwracają uwagę zawierające aluzje antyluterańskie programy dekoracji dostosowane do lokalnych potrzeb duszpasterskich lub stanowiące manifest wobec przywoływanych obszernie w ówczesnej prasie profanacji ${ }^{115}$.

Z perspektywy staropolskiej teorii wymaga namysłu sam wybór emblematyki do programu dekoracji. Nie bez znaczenia była zapewne znana z teorii rzemieślnicza kunsztowność i dworski wzorzec. Podobne filiacje przekładały się na rangę i kontekst przekazu, nie bez wpływu na wzmocnienie lub ewentualną polemiczność przesłania ${ }^{116}$. W przypadku dekoracji sakralnej emblematyczna inkrustacja mogła być odpowiednikiem dekorowanej szlachetnymi kamieniami Jeruzalem (Ap 21,18-21; w typologii biblijnej związek z Marią-Ecclesią) ${ }^{117}$, tłumacząc upodobanie emblematyki stosowanej w tematyce maryjnej.

Z referowanych fragmentów staropolskich definicji można ułożyć instrukcję klasyfikacji gatunkowej emblema w polskiej dekoracji, z zastrzeżeniem hipotetyczności rozwiązań i zaleceniem ostrożności w ich aplikowaniu. Wynika z nich w pierwszej kolejności konieczność dystansowania się od terminologii przekazu źródłowego (tak dekoracji, jak jej wzorca) i koncentrowanie się na źródłach związanych wyłącznie $\mathrm{z}$ autorem czy też kontekstem teoretycznym programu (np. w przypadku dekoracji jezuickiej lub powstałej przypuszczalnie z inspiracji jezuitów - teoria jezuicka) oraz na analizie dekoracji i słowno-obrazowej konstrukcji. Znajomość określonej teorii i dzieł przekładała się na rozumienie emblema (i innych gatunków) oraz na

114 Zob. I. Sapetowa, Monumentalne malarstwo nowożytne Polski południowo-wschodniej w jej obecnych granicach, w: Malarstwo monumentalne Polski południowo-wschodniej. Informator regionalny, Rzeszów 1995, s. 6-7; J. Pakulski, Barokowe inskrypcje w Ratuszu grudziądzkim, „Rocznik Grudziądzki” 16 (2005), s. 11-29.

11 Zob. Corpus Inscriptionum Poloniae, t. 5, z. 2: Miasto Łowicz, wyd. J. Szymczak, Warszawa-Łódź 1987, s. 165-166 (dekoracja kaplicy Najświętszego Sakramentu w katedrze w Łowiczu, A. Swach, 1718); M. Górska, Emblematyczna dekoracja fasad kolegium jezuitów w Toruniu (1701). Antyprotestancki program wedtug Imago primi saeculi Societatis Iesu (1640), „Zapiski Historyczne” 74 (2009), z. 1, s. 7-32.

116 Por. M. Górska, Motywy emblematyczne i heraldyczne w dekoracji malarskiej kościoła p.w. św. Jerzego $w$ Wilnie, w: Sztuka Kresów Wschodnich, t. 4, red. A. Betlej, P. Krasny, Kraków 1999, s. 71-80.

117 Por. S. Kobielus, Idea Niebiańskiej Jerozolimy w dekoracji monumentalnej kościoła św. Anny w Krakowie, „Rocznik Krakowski” 53 (1987), s. 39-62; M. Kurzej, Depingere fas est..., s. 113. 
sposób, w jaki adaptowano gatunek w dekoracji, na funkcję programu i formułę emblematów. W przypadku rekonstrukcji genologicznych pozbawionych przesłanek źródłowych próba klasyfikacji nie może być oddzielona od uwarunkowanego chronologicznie kontekstu teoretycznego: 1) emblema w rozumieniu historycznym (por. hierogliphicum, impresa, symbolum heroicum, tradycja epigramatyczna) lub emblema w ścisłym rozumieniu gatunku literackiego (do połowy XVII w.); 2) emblema w rozumieniu gatunku literackiego, pojmowane jako gatunek niezależny lub podporządkowany teorii symbolum (druga połowa XVII w.); 3) emblema w rozumieniu niezależnego gatunku literackiego lub jako element symbolografii i kompendiów, identyfikowany genologicznie wyłącznie w przypadku ustalenia konkretnego źródła przedstawienia (koniec XVII w.-XVIII w.).

Podkreślić trzeba, iż uwagi teoretyczne oprócz szczegółów dotyczących części emblematu przedstawiają odmienną od dwudziesto- i dwudziestopierwszowiecznych przyzwyczajeń i analiz hierarchię problemów, inaczej rozkładając akcenty definicji. Liczba elementów konstrukcji była drugorzędna wobec kwestii technicznych, kontekstu historycznego oraz znaczeniowego. Ważniejsze dla specyfiki gatunku były także wytyczne dotyczące narracyjności ikonu i formuły inskrypcji, szczególnie istotne dla emblematyki stosowanej. Dzięki dawnej teorii można w precyzyjniejszy sposób wskazać i ocenić daną kompozycję z punktu widzenia sztuki emblematu, wyraźnie oddzielić kompozycję emblematyczną od wzoru emblematycznego oraz uzupełnić analizę programu dekoracji o wątki, które nie wynikają bezpośrednio z kompozycji ikonu, ale z kontekstowej analizy konstrukcji złożonej oraz wzajemnych odniesień emblematów (i ich części) współtworzących program. Użyteczne z punktu widzenia praktyki badawczej, choć niewątpliwie wymagające analitycznie, są zalecenia dotyczące znaczenia pozyskanego dzięki insertio, pozwalające rozpatrywać w kategorii emblematu obrazy (ikony) pozbawione lemmy, także w ramie wydawniczej. Rozpoznanie i przebadanie przedstawień tego typu umożliwiłoby wyraźniejsze oddzielenie sztuki emblematycznej od wyobrażeń hieroglificznych i symbolicznych, a w konsekwencji - docenienie walorów formalnych i intelektualnych emblematyki stosowanej, precyzyjniejsze posługiwanie się terminologią oraz opracowanie katalogu polskich dekoracji emblematycznych.

\section{Bibliografia}

\section{Źródła}

Rękopisy

Biblioteka Gdańska PAN: rkps Ms. 2808.

Biblioteka Jagiellońska w Krakowie: rkps 2723 I, 3278 I, 3546, 4273, 7200 I.

Biblioteka Kórnicka PAN: rkps 318, 600, 619, 624. 
Biblioteka Książąt Czartoryskich w Krakowie: rkps 1867 IV, 2050, 2373 I, 2455 I.

Biblioteka Litewskiej Akademii Nauk w Wilnie: rkps F9-19, F9-330, F41-612, F255-1469.

Biblioteka Narodowa w Warszawie: rkps I 6881, akc. 2013.

Biblioteka Naukowa PAU i PAN w Krakowie: rkps 556, 557, 1332, 1747.

Biblioteka Uniwersytetu Wileńskiego: rkps F3-1067, F3-1521, F3-1812, F-2075, F3-2087, F3-2103, F3-2126, F3-2132, F3-2217, F3-2267.

Biblioteka Zakładu Narodowego im. Ossolińskich we Wrocławiu: rkps 1170/I, 1712/I, 5176/I, $5333 / \mathrm{I}$.

Lwowska Narodowa Naukowa Biblioteka Ukrainy im. W. Stefanyka, fond 4, opys 1, rkps 219, 414, 454, 457, 463, 476, 477, 478, 1483.

\section{Druki}

Bystrzonowski W., Informacyja matematyczna rozumnie ciekawego Polaka świat cały, niebo i ziemię, i co na nich jest, $w$ trudnych kwestiach i praktyce, jemuż ułatwiajaca, Lublin: Drukarnia Jezuitów, 1743.

Calepinus A., Dictionarium undecim linguarum, Basel: Heinrich Petri, 1558.

Chmielowski B., Nowe Ateny [...], Lwów: Drukarnia Kolegium Jezuitów, 1756.

Chmielowski B., Nowe Ateny. Umbry objaśnione, oprac. J. Kroczak, J. Sokolski, wstęp J. Sokolski, Wrocław 2015.

Dasypodius P., Dasypodius Catholicus, hoc est Dictionarium Latino-Germanico-Polonicum, Germanico-Latinum et Polono-Latino-Germanicum [...], Gdańsk: Andrzej Hünefeld, 1642.

Engelgrave H., Lux Evangelica [...], t. 2, Amsterdam: Jacob van Meurs, 1655.

Jardin sentimental du château de Warkland, dans le comté de Borch, en Russié Blanche, [Warszawa: s.n.] 1795.

Ketten J.M. von der, Apelles symbolicus exhibens seriem amplissimam symbolorum [...], Amsterdam-Gdańsk: J. Janssonius Van Waesberge - Erven, 1699.

Knapiusz G., Thesauri Polono Latino Graeci [...] tomus secundus [...], Kraków: Franciszek Cezary, 1626.

Knapiusz G., Thesauri Polonolatinograeci [...] Tomus secundus Latino Germano Polonicus [...] Editio nova correctior, Poznań: Drukarnia Kolegium Jezuitów, 1698.

Kwiatkiewicz J., Svada civilis huius aevi genis et nostratis politiae ingenio [...] accomodata [...], Kalisz: Drukarnia Jezuitów, 1672.

Labbé (L'Abbé) P., Elogia sacra, theologica et philosophica regia, eminentia, illustria, historica, poetica, miscellanea, accessere Stephani Petiot panegyrici duo [...], Lipsk: Johann Friedrich Gleditsch, 1686.

Ménestrier C.F., Philosophia imaginum [...], Amsterdam-Gdańsk: J. Janssonius Van Waesberge - Erven, 1695.

Pastorius J., Palaestra nobilium seu consilium de generosorum adolescentum educatione in gratiam quorundam Illustrium Polonorum conscriptum, Elbląg: nakładem autora; Achacy Korel, 1654.

Sandt van der M., Theologia symbolica. In qua origo symbolorum, eorumq[ue] artificium, ex Sacra Scriptura potissimum eruitur et eiusdem symbola omnis generis explicantur [...], Mainz: Johann Theobald Schönwtter, 1626. 
Szulc A., Orbis quod vult in obiectis centum scientiarium [...], Gdańsk: David Friedrich Rhete, 1682.

Temberski A., Via Appia ad eloquentiae lauream [...] seu facilis modus proficiendi in rhetoricis [...], Poznań: Drukarnia Kolegium Jezuitów, 1712.

Trotz M.A., Nouveau dictionnaire françois, allemand et polonois [...], t. I, Leipzig: Johann Friedrich Gleditsch, 1747.

Typotius J., Symbola divina et humana pontificum, imperatorum, regum, Praha: [Jiří Černý (Nigrin)], 1601-1603.

Żera K., Fraszki i opowiadania, wyd. Z. Gloger, Warszawa 1893.

\section{Opracowania}

Architektur als Ort für Embleme. Beiträge zu einer Tagung des Kunsthistorischen Instituts der Christian-Albrechts-Universität zu Kiel am 26.01.2013. Mundus Symbolicus II, Kiel 2014.

Arranz J.J.G., La imagen desconcertada: teoría y práctica en la representación de la figura humana en las Imprese, w: Estudios sobre emblemática española. Trabajos del grupo de investigación Literatura emblemática hispánica (Universidade da Coruña), Edición al cuidado de S. López Poza, Ferrol 2000, s. 65-80.

Ars emblematica. Ukryte znaczenia w malarstwie holenderskim XVII w. Katalog wystawy [Muzeum Narodowe w Warszawie], [oprac. J. Michałkowa et al.], Warszawa 1981.

Außerliterarische Wirkungen barocker Emblembücher. Emblematik in Ludwigsburg, Gaarz und Pommersfelden, hrsg. von W. Harms, H. Freytag, München 1975.

Bagley A., English Dictionary Definition of “Emblem” and “Device” from Elyot to Johnson, „Emblematica" 4 (1989), no. 1, s. 177-199.

Bania Z., Pałac w Podhorcach, „Rocznik Historii Sztuki” 13 (1981), s. 97-170.

Bath M., Books and Buildings: Recursive Emblems in the Applied Arts, „Emblematica” 22 (2016), s. 167-192.

Bath M., Inserts and Suppressions: Seventeenth-Century Poetic Usage of the Term "Emblem", w: Emblem Studies in Honour of Peter M. Daly, ed. by M. Bath, P.F. Campa, D.S. Russell, Baden-Baden 2002, s. 1-14.

Bednarska J., Z dziejów polskiej ilustracji panegirycznej pierwszej połowy XVII wieku, cz. 2: Problematyka stylistyczno-formalna polskiej panegirycznej ilustracji książkowej, Katowice 2005.

Bednarska J., Z dziejów polskiej ilustracji panegirycznej drugiej połowy XVII wieku, cz. 3: Studium z zakresu ikonografii i problematyki stylistyczno-formalnej, Katowice 2016.

Bentkowska A., Symbolika drzewa. Dylematy związane z emblematyczna metoda interpretacji malarstwa, „Rocznik Historii Sztuki” 15 (1985), s. 261-271.

Betlej A., Jan Stanisław Jabłonowski a sztuka w świetle jego pamiętników, „Barok” 13 (2006), nr 2 (26), s. 163-186.

Białostocki J., Kompozycja emblematyczna epitafiów śląskich XVI wieku, w: Ze studiów nad sztuką XVI wieku na Ślasku i w krajach sąsiednich, red. B. Steinborn, Wrocław 1968, s. 77-93.

Birecki P., Skrzynka cechu piwowarów na tle XVIII-wiecznej intarsji toruńskiej, „Rocznik Muzeum w Toruniu" 10 (2001), s. 177-211. 
Brożek A., Przyczynki do teorii definicji, „Filozofia Nauki/The Philosophy of Science” 26 (2018), nr 2 (102), s. 119-150.

Buchwald-Pelcowa P., Emblematy w drukach polskich i Polski dotyczących XVI-XVIII wieku. Bibliografia, Wrocław 1981.

Buchwald-Pelcowa P., Na pograniczu emblematów i stemmatów, w: Słowo i obraz. Materiały Sympozjum Komitetu Nauk o Sztuce Polskiej Akademii Nauk, Nieborów 29 września - 1 października 1977, red. A. Morawińska, Warszawa 1982, s. 73-95.

Caldwell D., The Sixteenth-Century Italian Impresa in Theory and Practice, New York 2004.

Campa P.F., Emblematic Terminology in the Spanish Tradition, w: Aspects of Renaissance and Baroque symbol Theory 1500-1700, ed. by P.M. Daly, J. Manning, New York 1999, s. 13-26.

Campa P.F., The Space between Heraldry and the Emblem: The Case of Spain, w: Emblem Scholarship Directions and Developments: A Tribute to Gabriel Hornstein, ed. by P.M. Daly, Turnhout 2005, s. 51-82.

Chojecka E., Dekoracja malarska ksiag promotionum i diligentiarum Uniwersytetu Jagiellońskiego XVI-XVIII wieku, Kraków 1965 (Zeszyty Naukowe Uniwersytetu Jagiellońskiego XCV, Prace z Historii Sztuki, z. 3).

Chrościcki J.A., La simbologia del potere nella decorazione di Dobromil, „Odrodzenie i Reformacja w Polsce" 39 (1995), s. 123-132.

Chrościcki J.A., Wojna i pokój $w$ przedstawieniach emblematycznych za panowania Wazów, w: Słowo i obraz. Materiały Sympozjum Komitetu Nauk o Sztuce Polskiej Akademii Nauk, Nieborów 29 września - 1 października 1977, red. A. Morawińska, Warszawa 1982, s. $129-150$.

Chrzanowski T., Emblematyka - sztuka manieryzmu czy baroku?, w: Sztuka baroku. Materiały Sesji naukowej ku czci śp. Profesorów Adama Bochnaka i Józefa Lepiarczyka zorganizowanej przez krakowski oddział Stowarzyszenia Historyków Sztuki i Instytut Historii Sztuki UJ, Kraków, 8-9 czerwca 1990 roku, red. M. Fabiański, K. Kuczman, Kraków 1991, s. $39-46$.

Cieślak K., Emblematyka w XVII-wiecznych wnętrzach kościelnych Gdańska, w: Sztuka XVII wieku w Polsce. Materiały Sesji Stowarzyszenia Historyków Sztuki, Kraków, grudzień 1993, red. T. Hrankowska, Warszawa 1994, s. 206-210.

Cieślak K., Emblematic Programmes in Seventeenth-Century Gdansk Churches in the Light of Contemporary Protestantism: An Essay and Documentation, „Emblematica” 9 (1995), no. 1, s. $21-44$.

Cieślak K., Między Rzymem, Wittenbergą a Genewą. Sztuka Gdańska jako miasta podzielonego wyznaniowo, Wrocław 2000.

Corpus Inscriptionum Poloniae, t. 5, z. 2: Miasto Łowicz, wyd. J. Szymczak, Warszawa-Łódź 1987.

Cubrzyńska-Leonarczyk M., Wiencek I., Grafika polska w starym druku - terra incognita? Z problemów rejestracji i opracowania, w: Metodologia, metoda i terminologia grafiki i rysunku. Teoria i praktyka, red. J. Talbierska, Warszawa 2014, s. 115-129.

Czarski B., Lemmata w staropolskich konstrukcjach stemmatycznych jako przejaw hybrydyzacji gatunkowej, „Terminus” 14 (2012), z. 25, s. 157-178.

Czarski B., Stemmaty w staropolskich książkach, czyli rzecz o poezji heraldycznej, Warszawa 2012 (Silva Rerum). 
Daly P.M., Directions in Emblem Research - Past and Present, „Emblematica” 1 (1986), no. 1, s. 159-174.

Daly P.M., The Emblem in Early Modern Europe: Contributions to the Theory of the Emblem, Farnham-Burlington 2014.

Daly P.M., The Emblem in Material Culture, w: Companion to Emblem Studies, ed. by P.M. Daly, New York 2008, s. 411-445.

Daly P.M., Emblem Studies: Achievements and Challenges, w: The International Emblem: From Incunabula to the Internet; Selected Proceedings of the International Conference of the Society for Emblem Studies, 28th July - 1st August, 2008, Winchester College, ed. by S. McKeown, Cambridge 2010, s. 523-531.

Dekoninck R., Ad Imaginem. Status, fonctions et usages de l'image dans la littérature spirituelle jésuite du XVII siècle, Genève 2005.

Dekoninck R., Maximilianes Sandaeus (1578-1656) théoricien de l'image mystique et symbolique, w: Emblematic Images and Religious Texts: Studies in Honor of G. Richard Dimler, S.J., ed. by P.F. Campa, P.M. Daly, St. Joseph 2010, s. 171-181.

Die Domänen des Emblems: Außerliterarische Anwendungen der Emblematik, hrsg. von G.F. Strasser, M.R. Wade, Wiesbaden 2004.

Drysdall D.L., Occurences of the Word “Emblema” in Printed Works before Alciato, „Emblematica" 14 (2005), s. 299-325.

Emblems and Art History: Nine Essays, ed. by A. Adams assisted by L. Grove, Glasgow 1996 (Glasgow Emblem Studies I, 1996).

The Emblem and Architecture. Studies in Applied Emblematics from the Sixteenth to the Eighteenth Centuries, ed. by H.J. Böker, P.M. Daly, Turnhout 1999.

Emblemata. Handbuch zur Sinnbildkunst des XVI. und XVII. Jahrhunderts, Taschenausgabe, hrsg. von A. Henkel, A. Schöne, Stuttgart-Weimar 1996.

Fumaroli M., Lécole du silence. Le sentiment des images au XVII siècle, Paris 1994.

Golonka J., Dekoracja malarska kaplicy jasnogórskiej z XVII wieku, w: W kierunku chrześcijańskiej kultury, red. B. Bejze, Warszawa 1978, s. 693-707.

Gołąbek M., Epitafium Anny Pisarskiej w krużgankach dominikańskich w Krakowie, „Barok” 11 (2004), 1 (21), s. 41-54.

Górska M., Apelles symbolicus (1699) Johanna Michaela von der Kettena - źródło wiedzy o niezachowanych emblematach i inskrypcjach warszawskich, w: Kultura artystyczna Warszawy XVII-XXI w. Studia, red. Z. Michalczyk, A. Pieńkos, M. Wardzyński, Warszawa 2010, s. 97-109.

Górska M., The Definition of the Emblem: Models and Norms of the Genre: The Polish Perspective, w: Non-Classical Genres - Theory and Practice (Series: Early Modern Genre Theories and the Practice of Writing) [w druku].

Górska M., Dekoracja emblematyczna Sali Pospólstwa w Ratuszu Tarnowskim. Przykład polskiej recepcji Cardiomorphoseos (1645) Francesca Pony, „Rocznik Tarnowski” 13 (2008), s. 27-43.

Górska M., Dekoracja emblematyczna warszawskiej kamienicy Gerarda Kleinpoldta, „Barok” 22 (2015), nr 1 (43), s. 107-127. 
Górska M., Dwór i familia. Wizerunek magnaterii w dekoracji okazjonalnej XVIII stulecia, w: Dwory magnackie w XVIII wieku: rola i znaczenie kulturowe, red. T. Kostkiewiczowa, A. Roćko, Warszawa 2006, s. 111-136.

Górska M., Emblematyczna dekoracja fasad kolegium jezuitów w Toruniu (1701). Antyprotestancki program według Imago primi saeculi Societatis Iesu (1640), „Zapiski Historyczne” 74 (2009), z. 1, s. 7-32.

Górska M., Emblematyka czasów stanisławowskich - problematyka terminologiczna dekoracji okazjonalnych, w: „Skłócony naród, król niepewny, szlachta dzika?”. Polska stanisławowska $w$ świetle najnowszych badań, red. P. Ugniewski, Warszawa 2020, s. 35-60.

Górska M., Emblematyka w Rzeczypospolitej epoki oświecenia - metamorfozy tradycji symbolicznej, „XVIII amžiaus studijos” 6 (2020), s. 140-159.

Górska M., Hieroglifik w teorii Rzeczpospolitej (XVII-XVIII w.). Zarys problematyki, „Terminus” 14 (2012), z. 25, s. 15-46.

Górska M., Motywy emblematyczne i heraldyczne w dekoracji malarskiej kościoła p.w. św. Jerzego w Wilnie, w: Sztuka Kresów Wschodnich, t. 4, red. A. Betlej, P. Krasny, Kraków 1999, s. 71-80.

Górska M., O staropolskiej lemmie w teorii i praktyce, „Teksty Drugie” (2019), nr 2, s. 241-258.

Górska M., Recepcja francuskich książek emblematycznych i zbiorów symboli w Rzeczypospolitej XVII $i$ XVIII wieku, w: Francusko-polskie relacje artystyczne w epoce nowożytnej, red. A. Pieńkos, A. Rosales Rodriguez, Warszawa 2010, s. 55-65.

Górska M., Symbolika heraldyczna a teoria impresy. Przykład Orbis Polonus Szymona Okolskiego, „Rocznik Polskiego Towarzystwa Heraldycznego” seria nowa, 13 (2014), nr 24, s. 35-49.

Górska M., Ut pictura emblema? Teoria i praktyka, w: Ut pictura poesis/ Ut poesis pictura. O zwiazkach literatury i sztuk wizualnych od XVI do XVIII wieku, red. A. Bielak, opieka naukowa P. Stępień, Warszawa 2013, s. 31-46.

Górska M., Milewska-Waźbińska B., Rękopis BK II 263 (obecnie BK 391). Kórnicki zbiór emblematów ku czci Jana III Sobieskiego, w: De nuptiis Philologiae et Libri manuscripti, czyli co nowego mówią rękopisy. Zbiór studiów, red. A.P. Lew, P. Pludra-Żuk, Warszawa 2016, s. 189-212.

Graham D., Emblema Multiplex: Towards a Typology of Emblematic Forms, Structures and Functions, w: Emblem Scholarship Directions and Developments: A Tribute to Gabriel Hornstein, ed. by P.M. Daly, Turnhout 2005, s. 131-158.

Grześkowiak R., Firlejów jako Nowe Ateny. Nieznane emblematy Benedykta Chmielowskiego, w: Świt i zmierzch baroku, red. M. Hanusiewicz, J. Dąbkowska, A. Karpiński, Lublin 2002, s. $489-501$.

Grześkowiak R., Polska recepcja Pia desideria Hermana Hugona. Typy odbioru religijnych zbiorów emblematycznych, w: R. Grześkowiak, Dialogi dzieł dawnych. Studia o intertekstualności literatury staropolskiej, Gdańsk 2018, s. 169-218.

Grześkowiak R., Niedźwiedź J., Wstęp, w: M. Mieleszko, Emblematy, wyd. i oprac. R. Grześkowiak, J. Niedźwiedź, red. D. Chemperek, Warszawa 2010, s. 36-47.

Gulbińska-Konopa U., Konopa Ł., Odnalezione wzory graficzne późnorenesansowych polichromii $w$ tzw. Piwnicy pod Fortuna $w$ kamienicy Lubomelskich $w$ Lublinie, „Tabularium Historiae” 3 (2018), s. 77-112.

Harasimowicz J., Mors Janua Vitae. Śląskie epitafia i nagrobki wieku reformacji, Wrocław 1992. 
Harms W., The Investigation of Emblem Programmes in Buildings: Assumption and Tasks, w: The Emblem and Architecture: Studies in Applied Emblematics from the Sixteenth to the Eighteenth Centuries, ed. by H.J. Böker, P.M. Daly, Turnhout 1999, s. 3-16.

Heckscher W.S., Wirth K.A., Emblem, Emblembuch, w: Reallexikon zur deutschen Kunstgeschichte, Bd. 5: Email-Eselsritt, Stuttgart 1959, szp. 85-228.

Höltgen K.J., Emblematic Title Pages and Frontispieces: The Case of Early Modern Period, w: Companion to Emblem Studies, ed. by P.M. Daly, New York 2008, s. 393-409.

Hundemer M., Rhetorische Kunsttheorie und barocke Deckenmalerei. Zur Theorie der Sinnlichen Erkenntnis im Barock, Regensburg 1997.

In laudes Ioannis Sobiescii. Rękopiśmienny zbiór emblematów z rysunkami Johanna Jakoba Rollosa, przeł. B. Milewska-Waźbińska, wstęp i oprac. M. Górska i B. Milewska-Waźbińska, Warszawa 2016 (Silva Rerum).

The Italian Emblem: A Collection of Essays, ed. by D. Mansueto in collaboration with E.L. Calogero, Glasgow 2007.

Iwanoyko E., Apoteoza Gdańska - Program ideowy malowideł stropu Wielkiej Sali Rady w gdańskim ratuszu Głównego Miasta, Gdańsk 1976.

Iwanoyko E., Emblematyczne Sobiesciana Gotfryda Peschwitza, „Artium Quaestiones” 2 (1983), s. 11-33.

Jank T., Życie i twórczość malarska brata Adama Swacha (1668-1747), Kraków 2017.

Kaczmarek R., Witkowski J., Dekoracja malarska kaplicy Ksiażęcej w Lubiążu. Najwcześniejsze prace freskowe Willmanna, w: Willmann i inni. Malarstwo, rysunek i grafika na Ślasku i w krajach ościennych w XVII i XVIII wieku, red. A. Kozieł, B. Lejman, Wrocław 2002, s. 82-91.

Karpiński A., Krauze-Karpińska J., Jesienne porzadki w ujazdowskim ogrodzie Stanisława Herakliusza Lubomirskiego. Prywatność publiczna - prywatność prywatna, „Barok” 18 (2011), nr 2 (36), s. 109-129.

Karpowicz M., Łazienka St. Herakliusza Lubomirskiego. Pierwowzory graficzne dekoracji i próba interpretacji treści, „Biuletyn Historii Sztuki” 31 (1969), nr 4, s. 397-401.

Karpowicz M., Sala Horacego w Starym Otwocku. Z rozważań nad antykizacja treści, w: Muzeum i twórca. Studia z historii sztuki i kultury ku czci prof. dr Stanisława Lorentza, [kom. red. K. Michałowski et al.], Warszawa 1969, s. 327-347.

Karpowicz M., Nowe spojrzenie na fresk Biblioteki Jasnogórskiej i jego autora Giuseppe Viscontiego, „Studia Claromontana” 25 (2007), s. 667-682.

Karpowicz M., Sztuka oświeconego sarmatyzmu. Antykizacja i klasycyzacja w środowisku warszawskim czasów Jana III, wyd. 2 popr. i uzup., Warszawa 1986.

Katalog zabytków sztuki w Polsce, t. 11, red. T. Chrzanowski, M. Kornecki, z. 16: Powiat toruński, oprac. T. Chrzanowski, M. Kornecki, Warszawa 1972.

Kemp C., Angewandte Emblematik in süddeutschen Barockkirchen, München 1981.

Kiliańczyk-Zięba J., Sygnety drukarskie w Rzeczypospolitej XVI wieku. Źródła ikonograficzne i treści ideowe, Kraków 2015.

Kneblewski W., Freski Dankwarta na Jasnej Górze, „Kronika Diecezji Kujawsko-Kaliskiej” 8 (1914), nr 3, s. 89-94; nr 4, s. 111-120. 
Kobielus S., Idea Niebiańskiej Jerozolimy w dekoracji monumentalnej kościoła św. Anny w Krakowie, „Rocznik Krakowski” 53 (1987), s. 39-62.

Kolendo-Korczak K., Praecepta politica $w$ toruńskim ratuszu. Niezachowany cykl malowideł z Sali Rady $z 1603$ roku i jego europejski kontekst, Warszawa 2014.

Koutny-Jones A., A Noble Death: The Oleśnicki Funerary Chapel in Tartów, „Journal of the Warburg and Courtauld Institutes" 73 (2009), s. 169-205.

Kowalczyk J., Medaliony na pałacu Suchorabskich-Radziwiłłów w Lublinie i ich pierwowzory graficzne, w: Studia nad sztuką renesansu i baroku, t. 4, red. J. Lileyko, Lublin 2000, s. 7-57.

Kozak A., Związki literacko-obrazowe w utworze S. Piskorskiego Flores Vitae B. Salomeae, w: Słowo i obraz. Materiały Sympozjum Komitetu Nauk o Sztuce Polskiej Akademii Nauk, Nieborów 29 września - 1 października 1977, red. A. Morawińska, Warszawa 1982, s. $113-128$.

Kryczyński W., Pałac podhorecki w roku 1717. Opis podług inwentarza z 1717 roku, Złoczów 1914.

Kucała M., Opuszczenia składników wypowiedzi-sentencji emblematycznych z XVII wieku, w: Studia z historii języka polskiego i stylistyki historycznej ofiarowane profesor Halinie Wiśniewskiej na 50-lecie jej pracy naukowo-dydaktycznej, red. C. Kosyl, Lublin 2001, s. 111-117.

Kurzej M., Ikonografia malowideł w zakrystii (tzw. skarbcu) kościoła Dominikanów w Krakowie, w: Sztuka w kręgu krakowskich dominikanów, red. A. Markiewicz, M. Szyma, M. Walczak, Kraków 2013 (Studia i Źródła Dominikańskiego Instytutu Historycznego w Krakowie, 13), s. 787-810.

Kurzej M., Depingere fas est. Sebastian Piskorski jako konceptor i prowizor, Kraków 2018.

Liškevičienė J., XVI-XVIII amžiaus knygu grafika: herbai senuosiuose lietuvos spaudiniuose, Vilnius 1998.

Loach J., Architecture and Emblematics: Issues in Interpretation, w: Emblems and Art History: Nine Essays, ed. by A. Adams assisted by L. Grove, Glasgow 1996, s. 1-21.

Loach J., Menestrier's Emblem Theory, „Emblematica” 2 (1987), no. 2, s. 317-336.

Loach J., On Words and Walls, w: An Interregnum of the Sign: The Emblematic Age in France. Essays in Honour of Daniel S. Russell, ed. by D. Graham, Glasgow 2001, s. 149-170.

Łuszczek D.K., Jasnogórski refektarz, Warszawa-Częstochowa 1992.

MacPhail E., The Mosaic of Speech: A Classical Topos in Renaissance Aesthetics, „Journal of the Warburg and Courtauld Institutes" 66 (2003), s. 249-263.

Marcinowska M., Dwór peten barw. Architektura i dekoracja malarska dworu z Rdzawy w Sadeckim Parku Etnograficznym, Nowy Sącz 1997.

Matyaszczyk D., Pałac w Konarzewie, „Ochrona Zabytków” 52 (1999), nr 3 (206), s. 250-263.

Mączyński J., Lexicon Latino-Polonorum, Królewiec: Jan Daubmann, 1564.

Michałowska T., Staropolska teoria genologiczna, Wrocław 1974.

Moisan-Jablonski Ch., Źródła inspiracji i symbolika regencyjnych „,bram tryumfalnych” zdobionych emblematami z kościoła pw. Św. Tomasza Apostoła w Nowym Mieście Lubawskim, w: Europa, Rzeczpospolita, Prusy Królewskie. Nowożytność, red. D. Dettlaff, Puck 2018, s. 101-133.

Mosingiewicz A., Kaczor D., Emblematyka w służbie władzy. Adama Jacoba Martiniego corpus emblematicum, czyli projekt choragwi gdańskich straży obywatelskich z okazji intrady Ludwiki Marii Gonzagi do Gdańska w 1646 r., w: Sztuka w kręgu władzy. Materiały LVII 
Ogólnopolskiej Sesji Naukowej Stowarzyszenia Historyków Sztuki, poświęconej pamięci Profesora Szczęsnego Dettloffa (1878-1961) w 130. rocznicę urodzin, Toruń, 13-15 listopada 2008, red. E. Pilecka, K. Kluczwajd, Warszawa 2009, s. 161-178.

Mödersheim S., The Emblem in the Context of Architecture, w: Emblem Scholarship Directions and Developments: A Tribute to Gabriel Hornstein, ed. by P.M. Daly, Turnhout 2005, s. 158-175.

Nowak R., Zapomniane malowidła freskowe Michała Willmanna w pałacu opackim w Lubiażu, „Roczniki Sztuki Śląskiej” 14 (1986), s. 97-116.

Ostrowski J., Flores vitae B. Salomeae, nieznany cykl graficzny Jerzego Eleutera Szymonowicza-Siemiginowskiego, „Biuletyn Historii Sztuki” 35 (1973), nr 1, s. 43-52.

Pakulski J., Barokowe inskrypcje w Ratuszu grudziądzkim, „Rocznik Grudziądzki” 16 (2005), s. 11-29.

Patiejūniene E., Brevitas ornata. Mãžosios literatūros formos XVI-XVII amžiaus lietuvos didžiosios kunigaikštystès spaudiniuose, Vilnius 1998.

Pax et Bonum. Skarby klarysek krakowskich. Katalog wystawy. Arsenat, Muzeum Czartoryskich, wrzesień-październik 1999, red. A. Włodarek, Kraków 1999.

Pelc J., Obraz - słowo - znak. Studium o emblematach w literaturze staropolskiej, Wrocław 1975.

Pelc J., Słowo i obraz. Na pograniczu literatury i sztuk plastycznych, Kraków 2002.

Pielas M.S., Cztery portrety Zofii z Odrowążów Tarnowskiej-Kostkowej, fundatorki kolegium jezuitów w Jarosławiu, „Studia Wilanowskie” 15 (2004), s. 93-107.

Pokora J., Sztuka w stużbie reformacji. Śląskie ambony 1550-1650, Warszawa 1982.

Rudkowski T., Polichromia kościoła parafialnego w Nowym Mieście nad Warta (Problemy ikonograficzne), w: Studia nad renesansem w Wielkopolsce, red. T. Rudkowski, Poznań 1970 (Prace Komisji Historii Sztuki, t. 8, z. 3), s. 71-99.

Russell D.S., The Term “Emblème” in Sixteenth-Century France, „Neophilologus” 59 (1975), s. 337-351.

Sapetowa I., Monumentalne malarstwo nowożytne Polski południowo-wschodniej w jej obecnych granicach, w: Malarstwo monumentalne Polski południowo-wschodniej. Informator regional$n y$, Rzeszów 1995, s. 3-15.

Seidel-Grzesińska A., Elementy emblematyczne pomników sepulkralnych w kościele Pokoju w Świdnicy, w: O sztuce sepulkralnej na Śląku. Materiały z sesji Oddziału Wrocławskiego Stowarzyszenia Historyków Sztuki, 25-26 października 1996 roku, red. B. Czechowicz, A. Dobrzyniecki, Wrocław 1997, s. 87-104.

Sokolski J., Barokowa ksiega natury. O europejskiej symbolografii wieku siedemnastego, Wrocław 1992.

Sokolski J., Symbol, w: Słownik literatury staropolskiej. Średniowiecze - renesans - barok, red. T. Michałowska, przy udziale B. Otwinowskiej, E. Sarnowskiej-Temeriusz, wyd. 2, Warszawa 1998 (Vademecum Polonisty), s. 917-923.

Stahr M., Medale Wazów w Polsce. 1587-1668, Wrocław 1990.

Talbierska J., Grafika XVII wieku w Polsce. Funkcje, ośrodki, artyści, dzieła, Warszawa 2011.

Typographorum Emblemata: The Printer's Mark in the Context of Early Modern Culture, ed. by A. Wolkenhauer, B.F. Scholz, Berlin-Boston 2018.

Vuilleumier Laurens F., La raison des figures symboliques à la Renaissance et à l'âge classique. Etudes sur les fondements philosophiques, théologiques et rhétoriques de l'image, Genève 2000. 
Warncke C.P., Symbol, Emblem, Allegorie. Die zweite Sprache der Bilder, Köln 2005.

Wisłocki M., Sztuka protestancka na Pomorzu 1535-1684, Szczecin 2005.

Witwińska M., Osiemnastowieczna polichromia w jarosławskim kościele „Na Pólku” i jej twórcy, w: Wizerunki maryjne. Archidiecezja przemyska, diecezja rzeszowska. Materiały z VI Seminarium Oddziału Rzeszowskiego Stowarzyszenia Historyków Sztuki „Sacrum et decorum” w Jarosławiu w dniach 16 i 17 listopada 1990 r., z. 1, red. I. Sapetowa, Rzeszów 1992, s. 43-59. Witwińska M., Ostrołęcka polichromia Walentego Żebrowskiego, „Biuletyn Historii Sztuki” 23 (1970), nr 3-4, s. 245-259.

Young A.R., The Emblem and Flags, w: Companion to Emblem Studies, ed. by P.M. Daly, New York 2008, s. 457-476.

Żukowski J., Żądza chwały. Władysław IV Waza w ikonografii performatywnej, Warszawa 2018.

\section{MAGDALENA KINGA GÓRSKA}

사 Instytut Badań Literackich PAN, Warszawa / The Institute of Literary Research of the Polish Academy of Sciences, Warsaw, Poland

@ magdalena.gorska[at]ibl.waw.pl

(D) https://orcid.org/0000-0001-5026-458X

Magdalena Kinga Górska is Assistant Professor at the Institute of Literary Research of the Polish Academy of Sciences (Warsaw). Research interests: emblem theory, applied emblematics, political iconography. Main publications: Polonia - Respublica - Patria. Personifikacja Polski w sztuce XVI-XVIII wieku (2005); The Protector of Europe: On Graphical Theses Glorifying Jan III Sobieski (2017); with Barbara Milewska-Waźbińska: In laudes Ioannis Sobiescii. Rękopiśmienny zbiór emblematów z rysunkami Johanna Jakoba Rollosa (2016).

This research received no specific funding. 